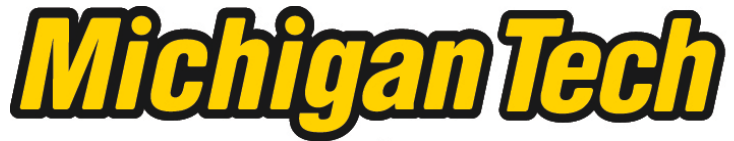 \\ Michigan Technological University Create the Future Digital Commons @ Michigan Tech
}

2012

\section{Suitability comparison of rainwater harvesting and piped water systems in the Dominican Republic}

Ryan M. Biehl

Michigan Technological University

Follow this and additional works at: https://digitalcommons.mtu.edu/etds

Part of the Civil and Environmental Engineering Commons

Copyright 2012 Ryan M. Biehl

\section{Recommended Citation}

Biehl, Ryan M., "Suitability comparison of rainwater harvesting and piped water systems in the Dominican Republic ", Master's report, Michigan Technological University, 2012.

https://doi.org/10.37099/mtu.dc.etds/520

Follow this and additional works at: https://digitalcommons.mtu.edu/etds

3 Part of the Civil and Environmental Engineering Commons 


\title{
A SUITABILITY COMPARISON OF RAINWATER HARVESTING AND PIPED WATER SYSTEMS IN THE DOMINICAN REPUBLIC
}

By

Ryan M. Biehl

\begin{abstract}
A REPORT
Submitted in partial fulfillment of the requirements for the degree of MASTER OF SCIENCE

Environmental Engineering
\end{abstract} MICHIGAN TECHNOLOGICAL UNIVERSITY 2012

(C) 2012 Ryan M. Biehl 
This report, A SUITABILITY COMPARISON OF RAINWATER HARVESTING SYSTEMS AND PIPED WATER SYSTEMS IN THE DOMINICAN REPUBLIC, is hereby approved in partial fulfillment of the requirements for the Degree of MASTER OF SCIENCE IN ENVIRONMENTAL ENGINEERING.

Department of Civil and Environmental Engineering

Signatures:

Report Advisor

Alex Mayer

Department Chair

David Hand

Date: 


\section{Table of Contents}

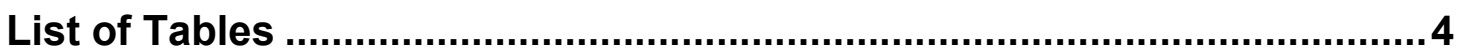

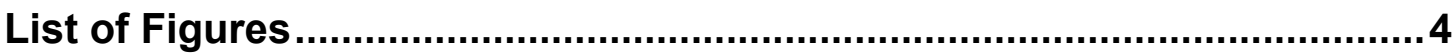

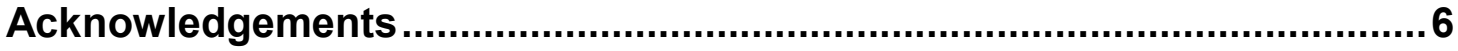

Abstract

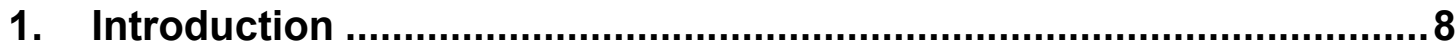

1.1. Motivation ............................................................................................................... 8

1.2. Literature Review ............................................................................................................... 12

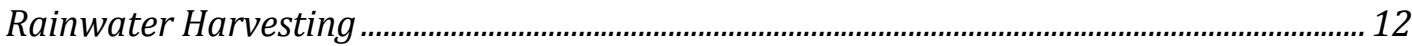

Demand thresholds in the Dominican context ................................................................................12

1.3. Hypothesis and objectives................................................................................................ 15

1.4. Background of study communities.............................................................................. 16

Agua de Luis and Los Derramaderos.......................................................................................16

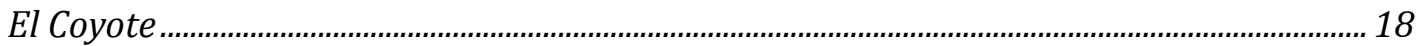

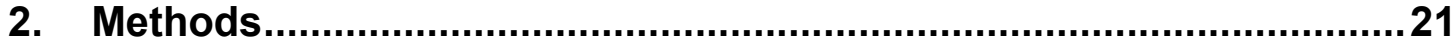

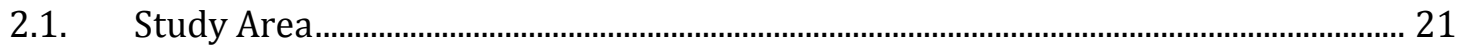

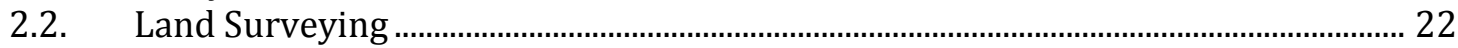

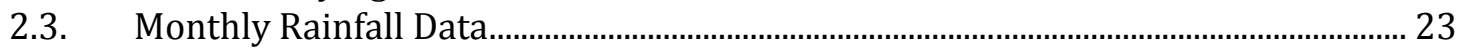

2.4. Roof Catchment Area and Water Storage Container Measurements .......................... 23

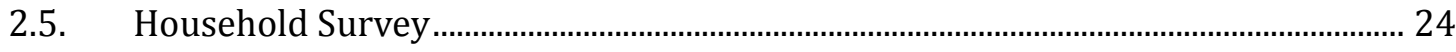

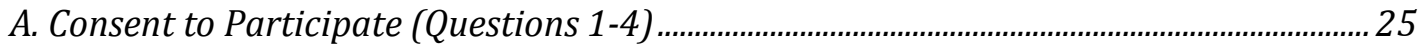

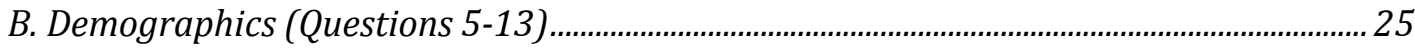

C. Current Water Sources (Questions 14-21).................................................................................25

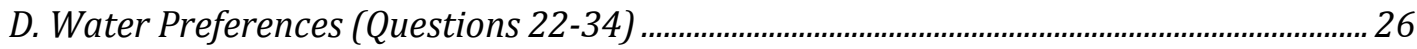

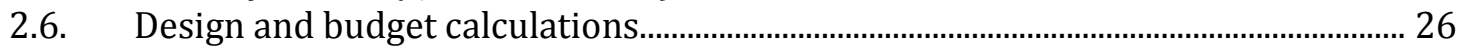

Rainwater Harvesting System Design ...........................................................................................2 27

Piped Distribution System Design ....................................................................................................29

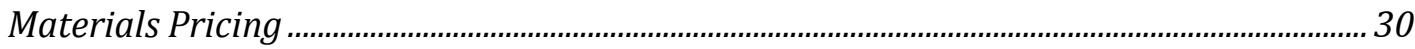

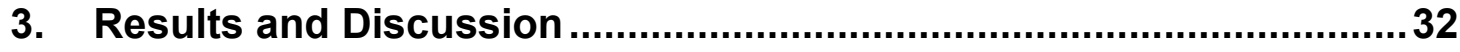

3.1. Monthly Rainfall Data......................................................................................................... 32

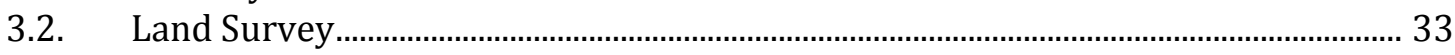

3.3. Household Survey …………………………………………………………………..... 34

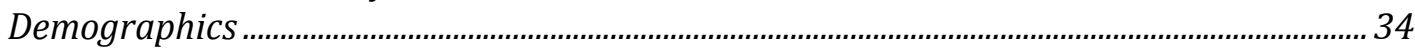

Current Water Resources.......................................................................................................................36

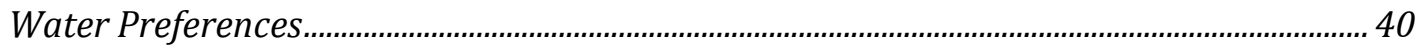

3.4. System Design and Budgeting …………………………………………………………… 45

Feasibility and Cost Analysis ............................................................................................................... 47

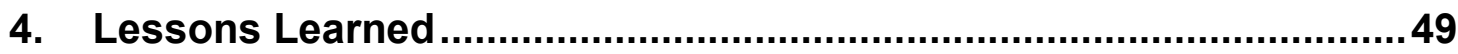

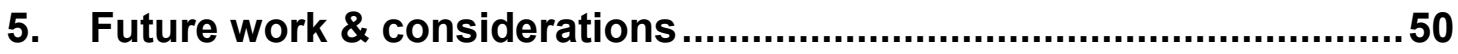

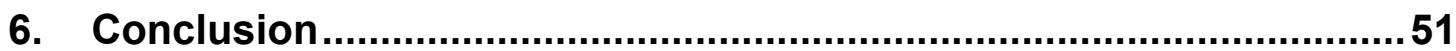

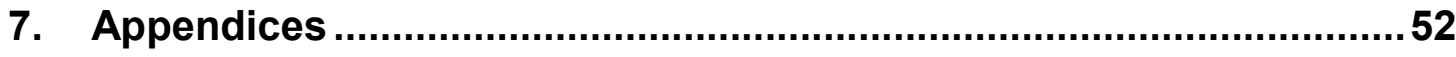

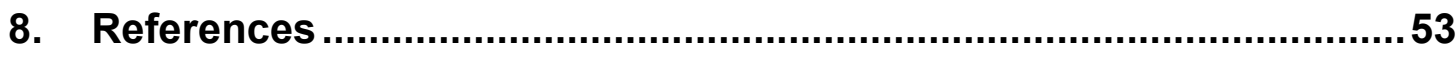




\section{List of Tables}

Table 1: Summary of water system improvement options for study communities ......22

Table 2: Summary of responses to demographic questions (q. 1-12) .........................35

Table 3: Highest level of formal education level achieved by respondents (q. 12).....36

Table 4: Summary of current water resources indicators averaged by community.......37

Table 5: Average household water storage volume by community............................37

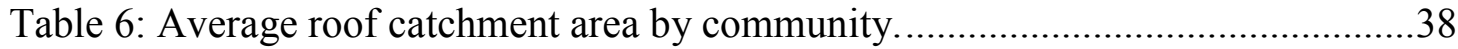

Table 7: Rankings of select water source alternatives according to potability (q. 26) and quantity available for other household uses (q. 27). .42

Table 8: Design summaries for piped water system options 45

Table 9: Estimated capital construction costs in \$US for water system improvement

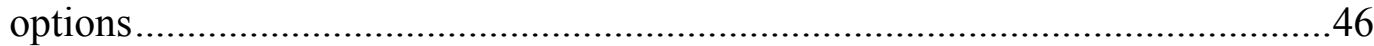

\section{List of Figures}

Figure 1: A work brigade digs trenches for the transmission line from the spring source to the ferro-cement water storage tank in Rio Grande al Medio. ................8

Figure 2: Masons and work brigade inside the water storage tank for Rio Grande al Medio Gravity-fed Water System during its construction..................................9

Figure 3: Informal domestic rainwater harvesting system at author's home in Dominican Republic.

Figure 4: Outdoor tap stand (left) and connection to a finished kitchen sink (right) from the spring-fed GFWS in Rio Grande al Medio.

Figure 5: RWH system in Los Derramaderos, Montecristi 10

Figure 6: Hierarchy of per capita water requirements (after Abraham Maslow's (1908-

1970) hierarchy of needs). .14

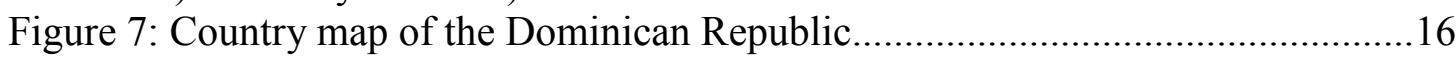

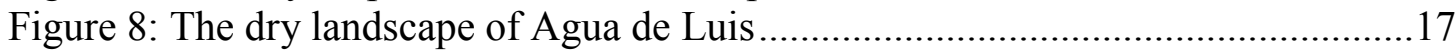

Figure 9: Water problems amidst lush vegetation in El Coyote, Samaná ....................19

Figure 10: Example sketch of a RWH system in Los Derramaderos. .........................24

Figure 11: Average monthly precipitation from historical record provided by

ONAMET at meteorological stations showing standard deviation .32

Figure 12: Monthly precipitation for 2011 provided by ONAMET at meteorological stations.

Figure 13: Land survey mapping: Agua de Luis and Los Derramaderos, Montecristi..

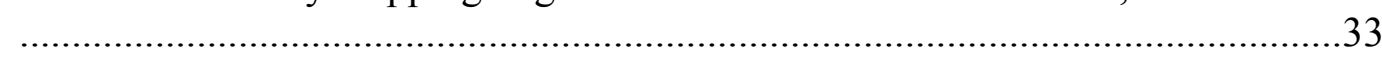

Figure 14: Land survey mapping: El Coyote, Samaná. ............................................34

Figure 15: Percentage of households meeting annual per capita water demand thresholds given current RWH system and roof area utilized

Figure 16: Percentage of households meeting annual per capita water demand thresholds if all potential roof area were utilized. 
Figure 17: Rankings by residents surveyed in Agua de Luis of water system improvement options according to potential impact on household water use considering quality and availability.

Figure 18: Rankings by residents of Los Derramaderos of water system improvement options according to potential impact on household water use considering quality and availability.

Figure 19: Rankings by residents of El Coyote of water system improvement options according to potential impact on household water use considering quality and availability.....

Figure 20: Rankings by residents of Agua de Luis of perceived capital costs of water system improvement options.

Figure 21: Rankings by residents of Los Derramaderos of perceived capital costs of water system improvement options.

Figure 22: Rankings by residents of El Coyote of perceived capital costs of water system improvement options. 


\section{Acknowledgements}

The successful completion of this report and of my service as a Peace Corps Volunteer in the Dominican Republic would not have been possible or as enjoyable without the help and support of so many. First and foremost, I would like to thank the Dominicans that made my two and a half years with them so interesting and enjoyable.

Agradezco a mi familia en la Sabana - A Yindo y a Thelma por cuidarme siempre como si fuera su propio hijo y por mantener mi barriga llena de con-con y habichuela. A los otros Sabaneros - jóvenes y mayores, grandes y pequeños - siempre les recordaré con mucho cariño como mis primos, tios, abuelos, y mejores amigos. Creo que jamás en mi vida voy a contar con vecinos tan buenos como ustedes. Agradezco a Francisca y Narciso por todo su esfuerzo y su amistad durante el proyecto del acueducto. Agradezco a los tigüeres (Lion y Estarlín) por siempre sacarme a gozar en el fin de semana y a todos los riogranderos por ser tan buenos conmigo. Era una experiencia inolvidable y regresaré a visitarles cuando puedo con gusto.

También agradezco a la gente de Agua de Luis, Los Derramaderos, y El Coyote quienes estaban tan graciosos conmigo durante este estudio. Gracias por aceptarme en sus casas sin conocerme para hablar y compartir conmigo. Conocer a ustedes fue la parte que mas me gusto de este proyecto.

Peace Corps is about family and community on every level. I thank the other Volunteers I served with in the D.R. for always being there for me and for each other. Special thanks to Eva Gougian, Ryan Browning, and Amanda Anderson for sharing your homes and insight with me during this study. Thank you Gabriel Miller for your help and comments this semester as I finished this report. Friends in the MTU Peace Corps Master's International program have been worth their weight in 'rice and beans' once returning home and I wish you all the best.

My faculty advisor, Dr. Alex Mayer has been there for me through my most meaningful experiences while associated with Michigan Tech. Your efforts and perseverance while communicating with me over the past years with motorcycles, music, and chickens roaring in the background are much appreciated as were advice and guidance given while writing this report. My other committee members, Dr. Hand and Dr. Sandoval also helped out while I was abroad. I thank you for the sincere interest you showed in my work.

Finally, I thank my family for supporting me as I left them for two years. I thank you for your prayers and I thank you and others for coming to visit me in Rio Grande.

Peace Corps teaches you that so many things are out of your control (Si Dios quiere...). I thank God and all of you who helped me, often without my knowing, for allowing my service and this report to be successful. 


\section{Abstract}

Rainwater harvesting (RWH) has a long history and has been supported as an appropriate technology and relatively cheap source of domestic water supply. This study compares the suitability of RWH and piped water systems in three rural Dominican communities seeking to improve their water systems. Ethnographic methods considering the views of residents and feasibility and cost analysis of the options were used to conclude that RWH is not a feasible or cost-effective solution for domestic water needs of all households in the communities studied. RWH investment is best left to individual households that can implement informal RWH with incremental increases in storage volume. Piped water distribution (PWD) systems perceived as too large or expensive to implement have much lower capital costs and are more supported by residents as a solution because they provide large quantities of water needed to maintain water services beyond mere survival levels. 


\section{Introduction}

\subsection{Motivation}

The author served in the Dominican Republic as a water and sanitation (Wat/San) engineer with the US Peace Corps between August 2009 and December 2011. The majority of this time was spent living in the rural community of Rio Grande al Medio (see map in Figure 7), where the primary project as a Volunteer was to plan, design, and construct a new gravity fed water system (GFWS) with the community. In addition to this, he supported the design, construction, repair, maintenance, and operation of other water systems - primarily in the North of the country - in collaboration with fellow Volunteers and Dominican counterparts. Through the challenges of this two-year process, the author learned firsthand much about the needs and attitudes of rural Dominicans regarding household water resources. The approach, methods, and technical choices used in the implementation of community water projects have been improved from year to year, as Wat/San Volunteers and Dominican counterparts (including Water Committee leaders and Technicians) maintain an open discussion of what works or not. The results of these discussions are passed on to future Volunteers and communities. Knowledge that was shared ranges from how to most efficiently organize a work brigade to dig a trench for laying pipe (Figure 1), to the implementation of more cost efficient ferro-cement construction for water storage tanks (Figure 2), to the training of water committees in effective techniques for fee collection.

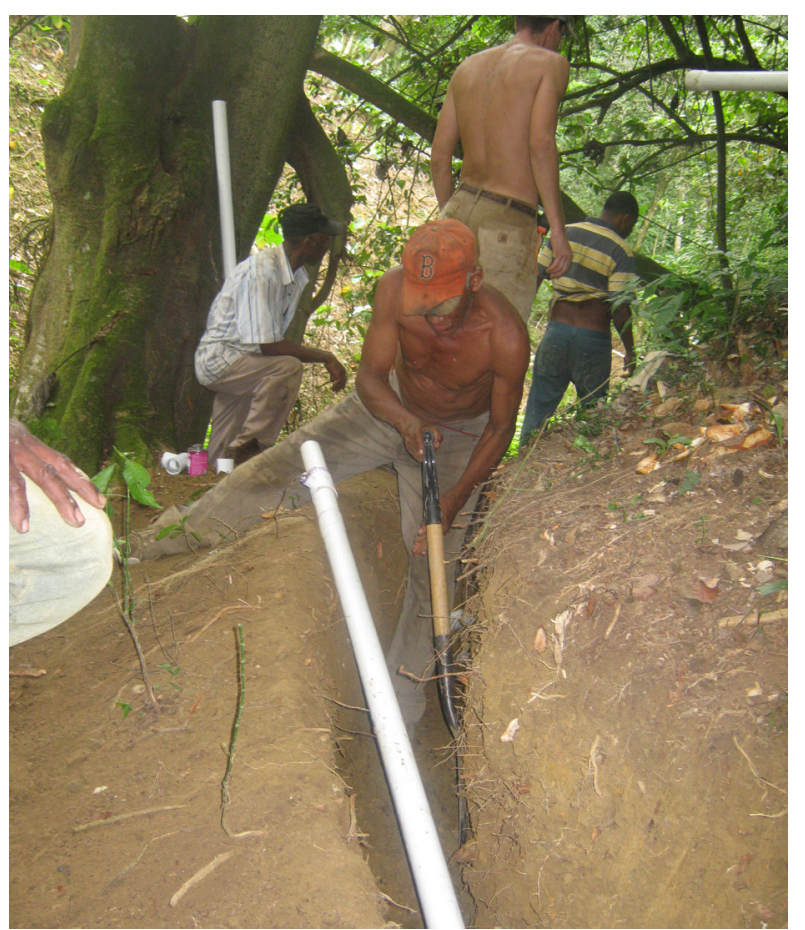

Figure 1: A work brigade digs trenches for the transmission line from the spring source to the ferro-cement water storage tank in Rio Grande al Medio. 


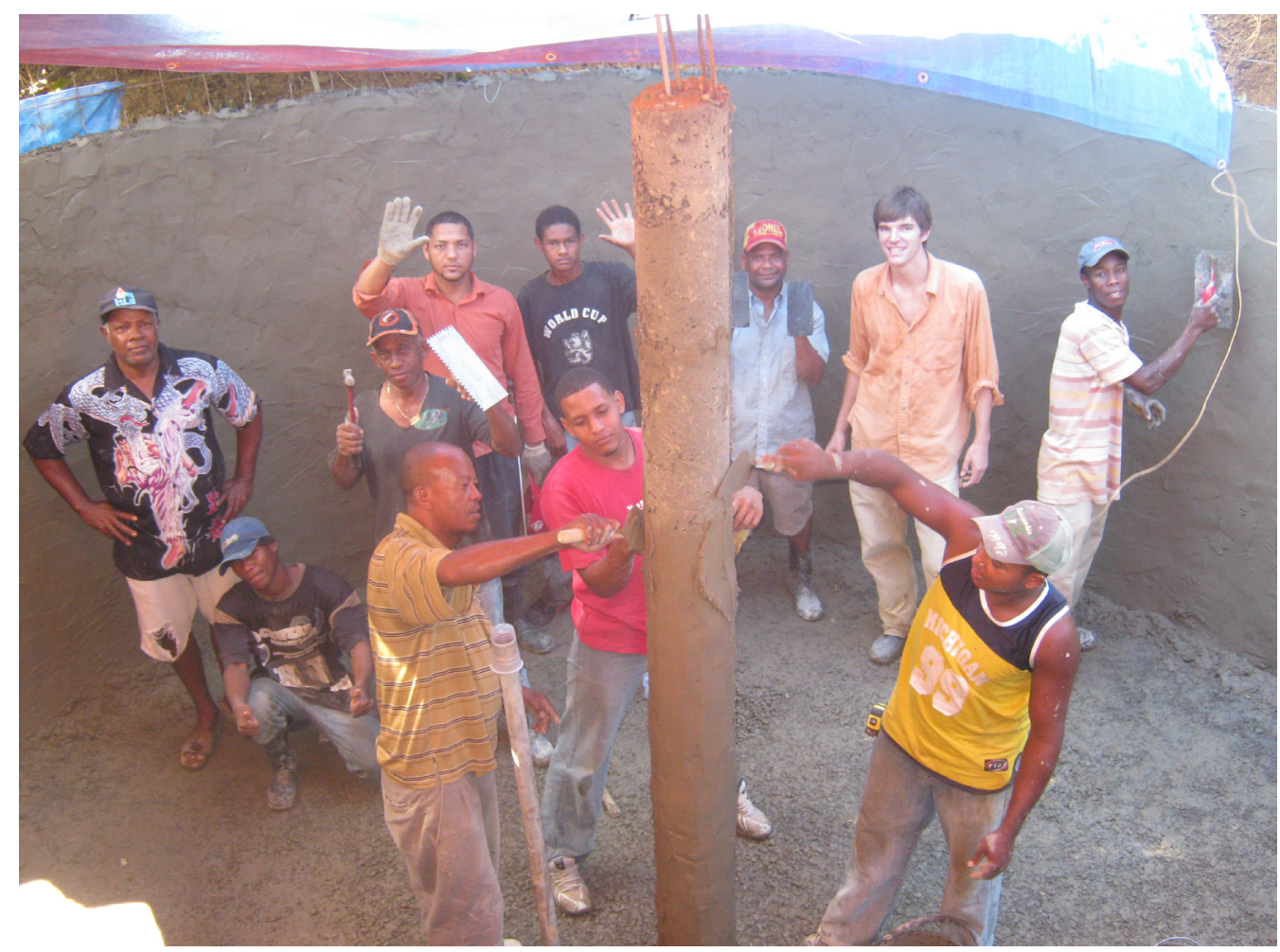

Figure 2: Masons and work brigade inside the water storage tank for Rio Grande al Medio Gravity-fed Water System during its construction.

Often, before and after the implementation of a water system improvement project, rural households rely on multiple sources for meeting water needs. For instance, in Rio Grande al Medio, prior to the construction of the new GFWS, households relied on an existing GFWS that provides unreliable service from a river; collection on foot of stream, river, and spring water in small containers; and informal rainwater harvesting $(\mathrm{RWH})$ systems, as shown in

Figure 3. The system shown in the picture is relatively quick to set up, requiring no more than a poly-vinyl-chloride (pvc) pipe cut down its length and attached to the eaves of the zinc roof, and a collection container under its lower end (here, a reused 55 gallon plastic barrel).

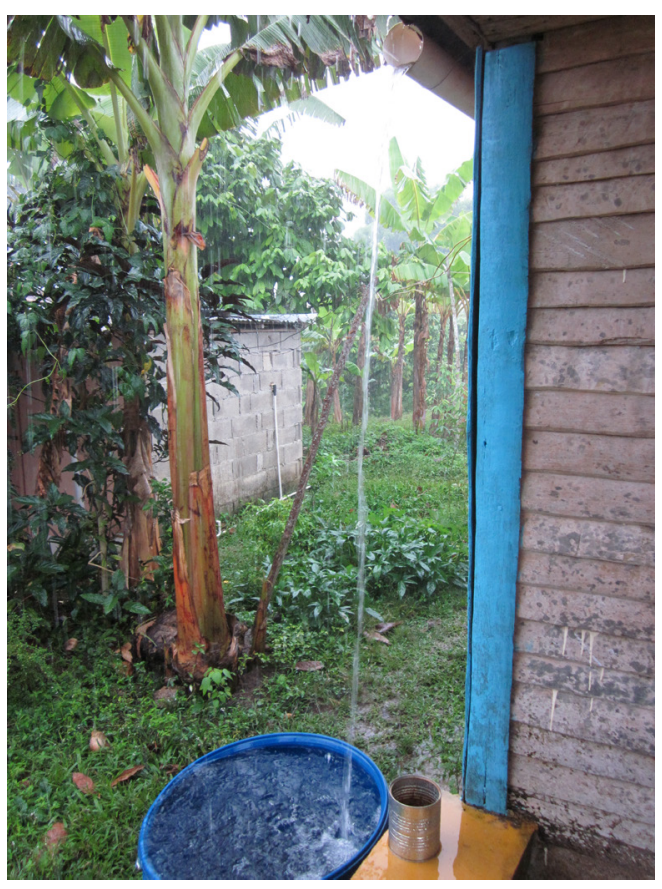

Figure 3: Informal domestic rainwater harvesting system at author's home in Dominican Republic. 
Just as existing water resources come from a variety of sources, there are multiple options for the implementation of water system improvement projects. The system chosen for implementation should depend on user demands and preferences, water resources available, and cost. The solution implemented during the author's service in Rio Grande resulted in connections being placed to individual households both as tap stands in the yard and connections inside the home as seen in Figure 4. This system was designed to provide a minimum of 45 liters per capita per day (lpcd) during the dry season.

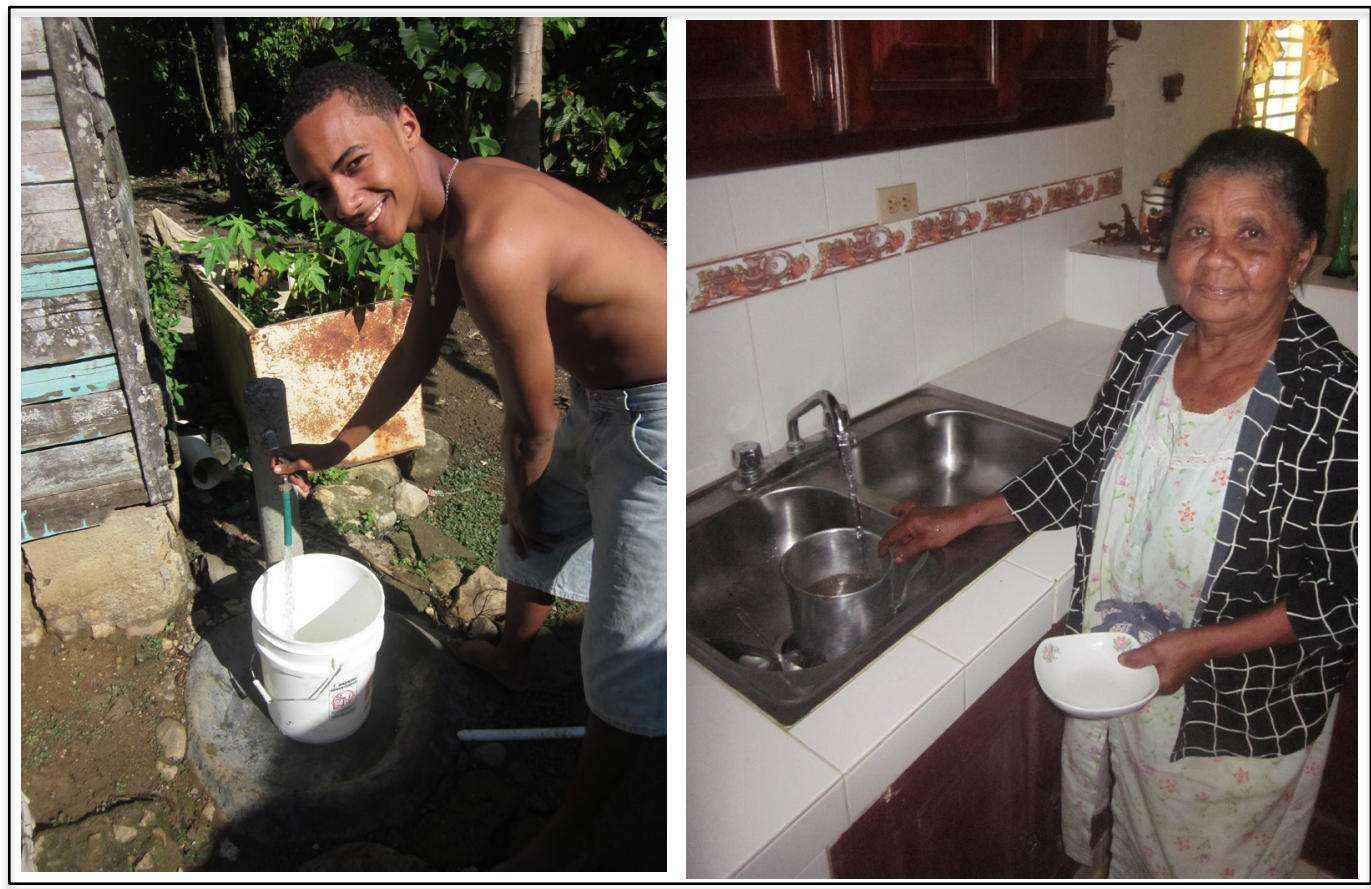

Figure 4: Outdoor tap stand (left) and connection to a finished kitchen sink (right) from the spring-fed GFWS in Rio Grande al Medio.

In communities where construction of a piped water distribution (PWD) system is considered infeasible for any number of reasons, private individuals and NGOs may implement RWH systems ranging in complexity from a cut bamboo conduit along an eave draining into a five gallon pail to formally designed collection systems using PVC pipes leading to large concrete storage tanks as seen in Figure 5. 


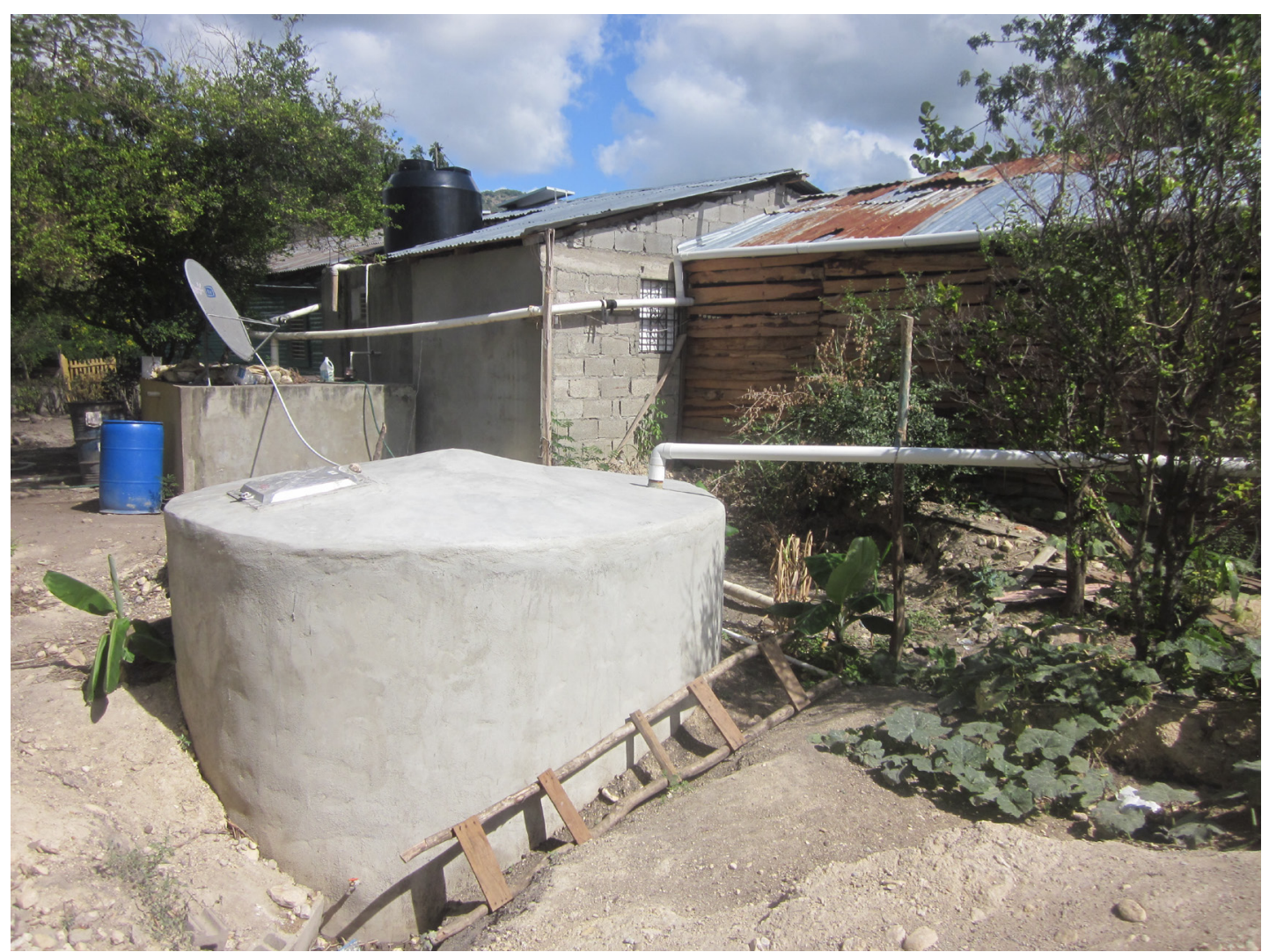

Figure 5: RWH system in Los Derramaderos, Montecristi: A block cistern constructed by the NGO PROLINO (background) and ferro-cement cistern constructed with homeowner's funding and technical support from Peace Corps Volunteers (foreground). PVC conduits bring water to the cisterns from various roofing areas.

Administrative and programmatic changes in Peace Corps' Dominican Republic (PCDR) Wat/San sector during the author's service culminated in efforts to expand water system improvement projects implemented by Peace Corps to RWH and other appropriate technologies. Prior to 2010, the program had been limited to GFWS projects. Given the prevalence of paternalism and corruption, water projects in the Dominican Republic often receive significant investment for initial construction but little post construction support (Schweitzer 2009). Intense training of water committees and the application of GFWS as an appropriate technology are approaches PCDR has used to encourage the sustainability of rural water systems in this difficult environment. Impetus for the shift towards RWH was a result of the application of ferro-cement tank construction, making large-scale RWH storage more cost effective than it was with cement block tanks. PCDR also desired to assist communities that were considered infeasible for the construction of PWD systems but still demonstrated a need for improved water systems. As PCDR began evaluating communities considered to be likely candidates for RWH system projects, Wat/San Volunteers who had accumulated significant experience working with GFWS and pumped distribution systems in the country wondered under what conditions rainwater harvesting systems would become a more feasible and desirable solution for a community than piped water distribution systems? Answering this question was the initial motivation for this study. 


\subsection{Literature Review}

\section{Rainwater Harvesting}

The history of rainwater harvesting dates back to ninth or tenth century Asia (Mihelcic, Fry et al. 2009). RWH has been used for agriculture and for groundwater recharge; this study focuses soley on rainwater harvested from household roof surfaces for domestic uses. There is growing interest, initiative, and investment in rainwater harvesting by donors (Gould and Nissen-Petersen 1999).The three basic components of a domestic RWH system are a catchment area, collection (such as guttering), and storage facilities (Pickford 1991). The volume of water that can be harvested is a function of these components and precipitation. Gould and Nissen-Petersen (1999) describes the relationship as follows:

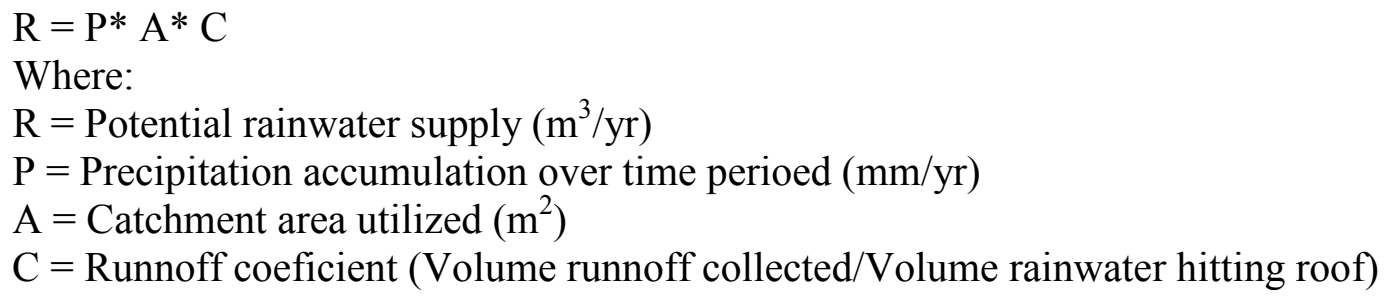

Area is dependent on the catchment surface, in this case a roof, as well as the extent of guttering that collects water from that surface. The runoff coefficient depends on roofing material, gutter type and system maintenance. The storage container volume determines how much of the potential rainwater supply throughout a year can be used to meet household demand. Gould and Nissen-Petersen (1999) describes a number of methods for determining storage volume to optimize supply for a catchment area or to meet a demand threshold.

The chief limitations of domestic RWH include the potential rainwater supply, as well as the cost of providing sufficient storage to endure dry seasons at demand thresholds (Thomas 2003). Assuming that annual rainfall reaching roof catchment areas is sufficient, the cost of formal RWH storage containers to meet demand during droughts throughout the year may be prohibitive. However, informal domestic RWH may be implemented at low cost as a suplemental water supply by households themselves (Thomas 2003). Despite its limitations, RWH is described as being a relatively cost effective improved water supply (Mihelcic, Fry et al. 2009).

\section{Demand thresholds in the Dominican context}

Whether or not RWH systems are feasible or cost effective can change from site to site. The presence of other water system improvement options and their costs and benefits must be considered along with RWH. The water needs and demands of a community depend on its habits, current water resources, and what residents percieve as a sufficient water supply. Considering this, it is important to consider the current targets for household water demand in the Dominican Republic. The Millenium Development Goals (MDG) define improved access as "at least 20 liters per capita per day from a protected source within $1 \mathrm{~km}$ of the user's dwelling" (Hutton and Bartram 
2008). MDG target 7.C was to halve, by 2015, the proportion of people without improved access to safe drinking water and basic sanitation. As of 2010, this goal had already been met ahead of time in the Dominican Republic, yet 1.3 million Dominicans still did not have sustainable access to drinking water. Disparity between rural and urban access still is significant. $91.7 \%$ of the urban population met the criteria in 2007 whereas only $73.3 \%$ of the rural population had improved access to potable water. As of 2006, disparity also existed between the wealthy and the poor. $13.5 \%$ of the fifth of the households reporting the highest incomes did not have improved access, whereas the percentage without access is $44.5 \%$ among the fifth of the population with lowest income (Monegro 2010).

The fact that the Dominican Republic has already met its MDG target for potable water indicates that the water system needs of the country as a whole have moved beyond simply surviving. However, disparity between rural and urban, rich and poor, underlines the need for continued effort. Despite living in rural areas, or having lower income, rural Dominicans expect and hope for water systems that their relatives and friends may enjoy in cities like Santiago, Santo Domingo, New York, and Miami. Connections between rural Dominicans and urban or transnational communities are strong. In the Dominican community of Miraflores, $65 \%$ of households have at least one member living in Boston (Levitt 2001). Where the author lived in Rio Grande, neighbors returned on the weekends from the city of Santiago where they worked and other relatives visited from abroad during holidays. In the author's experience, as in Miraflores, income, news, consumer goods, and values move in and out of rural Dominican communities from urban and foreign countries as frequently as 'absent' family members do. Just as this migration affects demand for consumer items, it also should be expected to affect demand for water supplies. A successful water system improvement in rural Dominican communities must provide high level of service at a low cost.

Figure 6, modified from a document prepared for the World Health Organization, summarizes the benefits associated with different thresholds of per capita water demand (Reed and Reed 2011). 


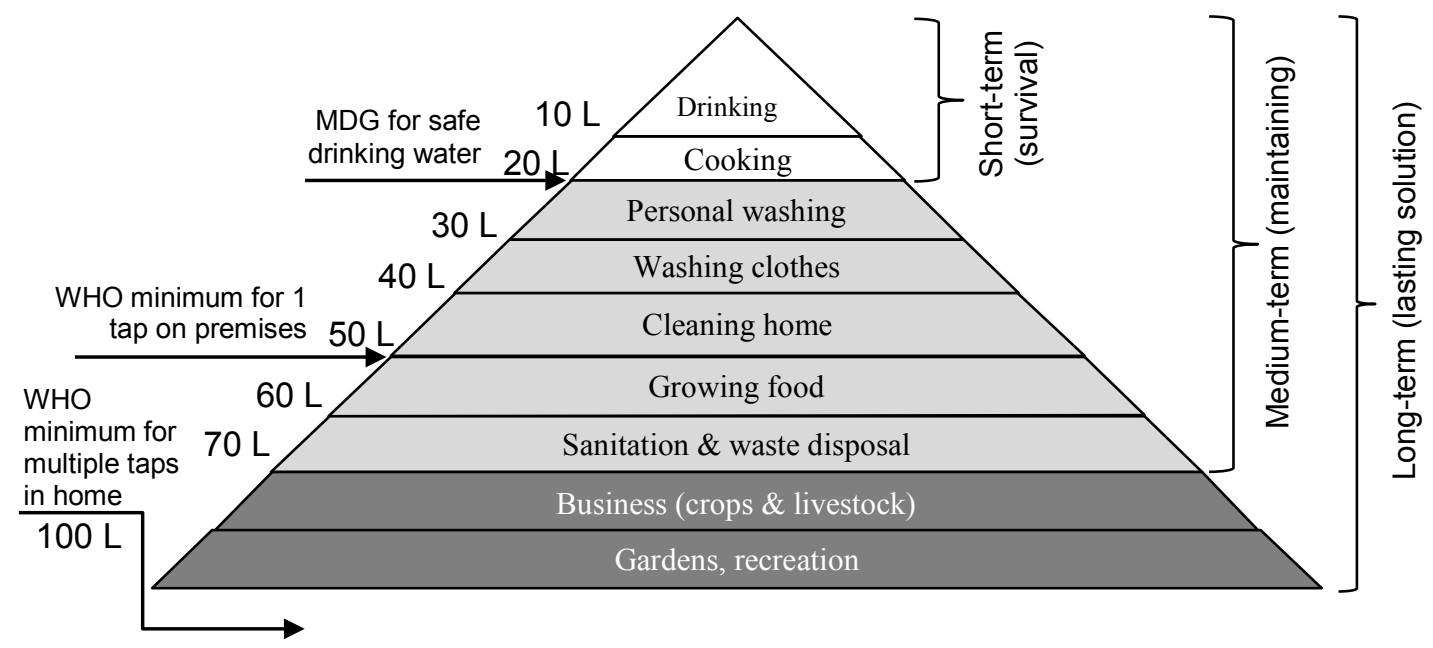

Figure 6: Hierarchy of per capita water requirements (after Abraham Maslow's (1908-1970) hierarchy of needs). Generally as water quantity increases, quality decreases. Arrows on left indicate demand thresholds designated by the Millennium Development Goals and the World Health Organization. Source: WHO / WEDC Loughborough University Adapted from: WHO / WEDC Loughborough University

The MDG target of 20 lpcd is defined above as meeting the needs of short-term survival. The other thresholds highlighted are 50 lpcd as 'intermediate access' and 100 lpcd as 'optimal access' (Howard and Bartram 2003). These thresholds are based on how much water can be expected to be used, considering ease of access, but also coincide with the benefits and uses listed in Figure 6. When considering the implementation of a long-term water system improvement, whether a ferro-cement RWH storage tank, or buried pipelines, it would be unwise to set the goal at only "survival". Where significant investment is involved, solutions which only support the top of this pyramid, without addressing the base seem unlikely to be supported or successful in communities. 


\subsection{Hypothesis and objectives}

Given the limitations of domestic RWH acknowledged in literature, the following hypothesis was tested within the context of the rural Dominican communities of Agua de Luis, Los Derramaderos, and El Coyote:

Rainwater harvesting systems when compared with even expensive or technically challenging piped water distribution systems are unable to provide water for domestic uses at a level and cost to which Dominican households are accustomed to and demand.

Each of these communities has been considered as a possible site for RWH projects and has identified different options for a piped water system considered difficult to implement. The objectives of this work were:

(a) to conduct an ethnographic study of the views of residents in community towards rainwater harvesting versus piped water distribution systems and

(b) to perform an engineering analysis of rainwater harvesting versus piped water distribution systems. 


\subsection{Background of study communities}

The communities studied were Agua de Luis, Los Derramaderos, and El Coyote (see Figure 7 for location). All three communities had expressed interest through Peace Corps Volunteers living in the communities to improve their water systems. PCDR considered them possible candidates for RWH system projects, and the author visited these communities in 2011 to evaluate the feasibility of RWH systems and other water projects for PCDR. These study sites are rural agricultural communities in the northern Dominican Republic that vary in geography, weather, and water system options.

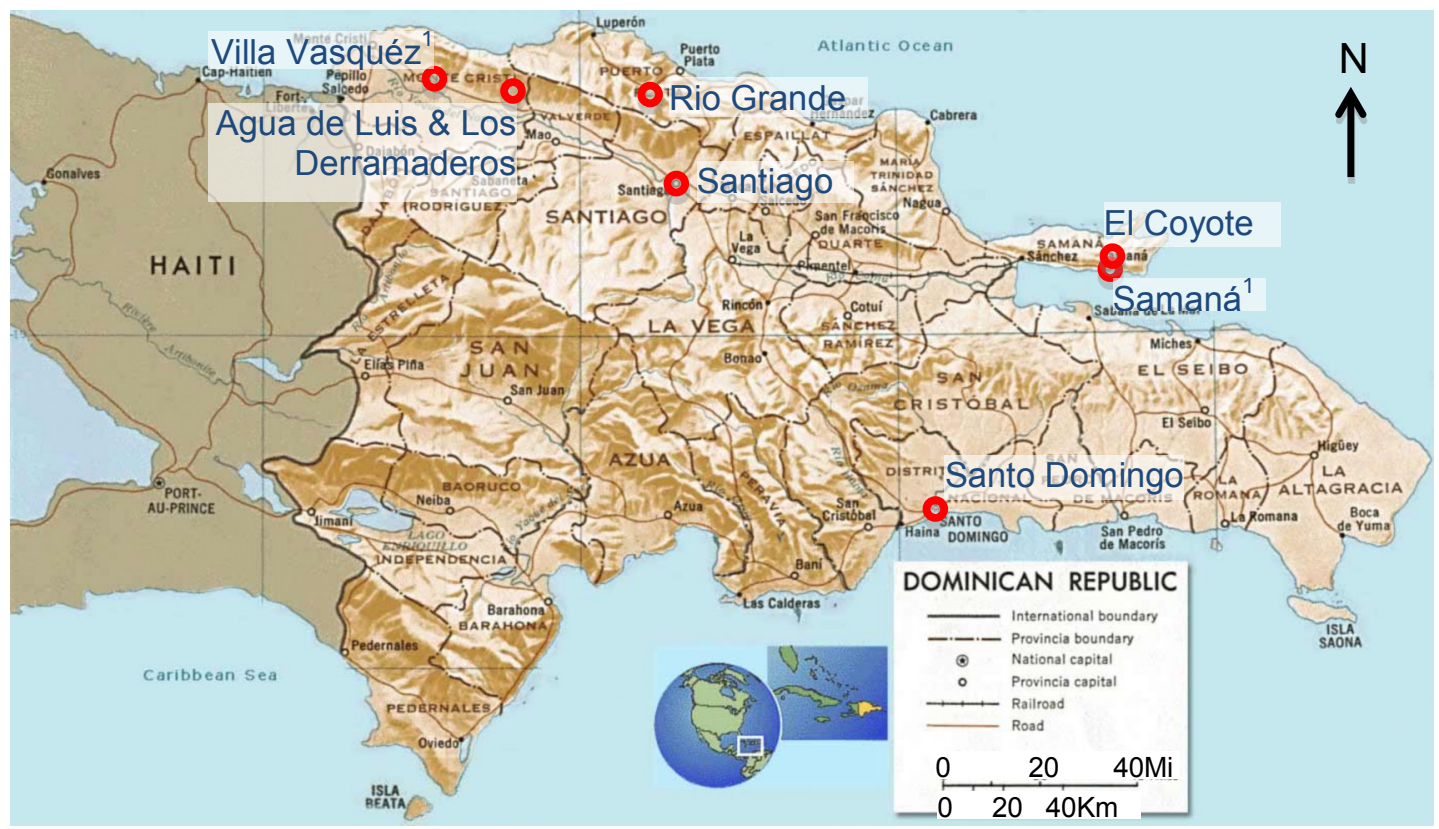

Figure 7: Country map of the Dominican Republic. Source: http://mapsof.net/uploads/staticmaps/dominican republic.jpg. Adapted courtesy of mapsof.net. ${ }^{1}$ Indicates approximate location of meteorological station.

\section{Agua de Luis and Los Derramaderos}

Agua de Luis and Los Derramaderos are neighboring communities located in the Province of Montecristi in the northwest of the country. The landscape is defined by sparse grazing lands and dry weather vegetation including cactus. On the north side of the communities, the mountains of the Cordillera Septentrional rise out of the plain, separating the region from the Atlantic coast and creating a rain shadow. The nearest meteorological station in Villa Vasquéz receives on average $759 \mathrm{~mm}$ of rainfall annually (Meteorología 2011). Villa Vasquéz is $25 \mathrm{~km}$ from Agua de Luis and Los Derramaderos and is at an elevation of $30 \mathrm{~m}$ above sea level (a.s.1.) (Google 2012), whereas elevations in Agua de Luis and Los Derramaderos are around $200 \mathrm{~m}$ a.s.l. The large city of Santiago is approximately an hour and a half away by public transportation. The communities can be reached by motorcycle taxi or in a private vehicle via a well maintained dirt road. 


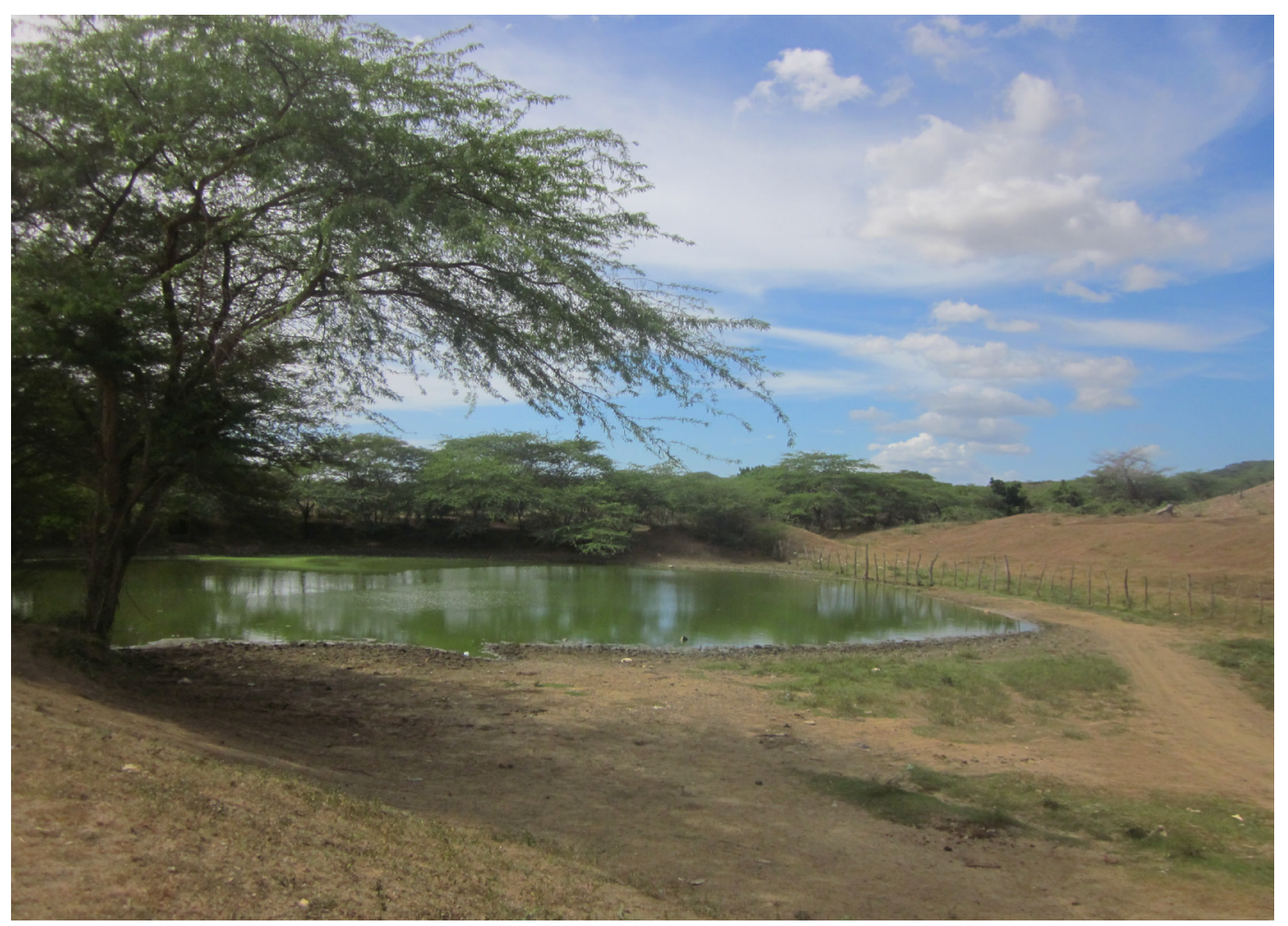

Figure 8: The dry landscape of Agua de Luis. Lagoons off the side of the dirt road collect runoff from the arid landscape. This water is mostly for cattle, but is sometimes used for households when preferred sources run short.

Between 1996 and 1999, the NGO Prolino built hundreds of RWH systems in the two communities in the form of concrete block cisterns, new zinc roofing, and gutters. These systems are still in use both for RWH and as storage for tanker trucks of water bought from government-subsidized and private providers. During the study, a PCV in Los Derramaderos was in the process of implementing a small project upgrading RWH collection with PVC gutters at a subsidized cost for some homes, and in Agua de Luis, a different PCV was in the planning stages of a project to build additional RWH ferro-cement storage tanks. Residents also collect water from lagoons as seem in Figure 8 and from springs.

A large piped water system that serves populations throughout the northwest Dominican Republic passes along the county seat of Hatillo Palma on the highway that leads to the border with Haiti. The PWD system, despite being completed in 2010 with a design life of 20 years, already fails to maintain regular service in the zone of Montecristi it was intended to serve (Reyes 2011). Water does not arrive every day in Hatillo Palma, but the fruit trees and gardens in residents yards are testaments to the benefits of this troubled water system. Many residents of Agua de Luis and Los Derramaderos have struggled, organized, and asked government officials to extend this water system to their communities from the larger town of Hatillo Palma located $10.3 \mathrm{~km}$ away and $129 \mathrm{~m}$ below Los Derramaderos on the highway. This project would require pumping and will be referred to as water system option P-1 in this report. 
Three springs are located in the hills north of Los Derramaderos, whereas Agua de Luis has no significant spring sources. According to residents, a GFWS was built in Los Derramaderos in the early 1990s using water from the spring 'El Naranjito' and ceased functioning before the year 2000. Public tap stands are still in place, but they no longer function. This water was initially used for household use primarily by the people of Los Derramaderos. The system did not reach Agua de Luis, although some residents fetched water at the tap stands in Los Derramaderos. Reasons given by residents of why the system failed include that the plumber who maintained the system passed away leaving no one else trained to continue his work; ranchers broke the pipes to divert water to cattle troughs; and the system was neglected after construction of RWH systems by PROLINO. Prior to and during the study, people in Los Derramaderos commented that the springs have gotten much drier. Visible and active deforestation for the creation of more crop and cattle land is acknowledged by community members as a cause of this change. Rebuilding the GFWS using all three spring sources has been considered as an option by some community members and PCVs. A spring-fed GFWS serving both Los Derramaderos and Agua de Luis will be referred to as P-2, and a spring-fed GFWS serving just Los Derramaderos will be labeled P-3 in this report.

At the time of the study, the author observed that residents had organized a political campaign threatening not to vote in upcoming presidential elections if improvements were not made before the election to 'water, electricity, and road' - water being of first priority among these.

\section{El Coyote}

El Coyote is located on the Samaná Peninsula in the northeast of the country. The community is perched along the ridge of a paved tourist highway that crosses the small city of Samaná proper below to the beach community of Las Terrenas on the Atlantic side of the peninsula. The lush vegetation in Coyote is supported by regular rainfall. The nearest meteorological is in Samaná proper and reports average annual precipitation of 2,199 $\mathrm{mm}$ (Meteorología 2011). The port of Samaná is approximately $4.7 \mathrm{~km}$ away at $15 \mathrm{~m}$ a.s.l. (Google 2012), whereas elevations in El Coyote are around $230 \mathrm{~m}$ a.s.l. Access to water is a challenge as surface water and spring sources are downhill of the community. Water sources include homemade RWH systems; collection of water from shallow wells, streams, and rivers all downslope from the homes; water bought from private vendors (Figure 9); and fetching water with a vehicle from piped water systems serving other communities (also downslope). 


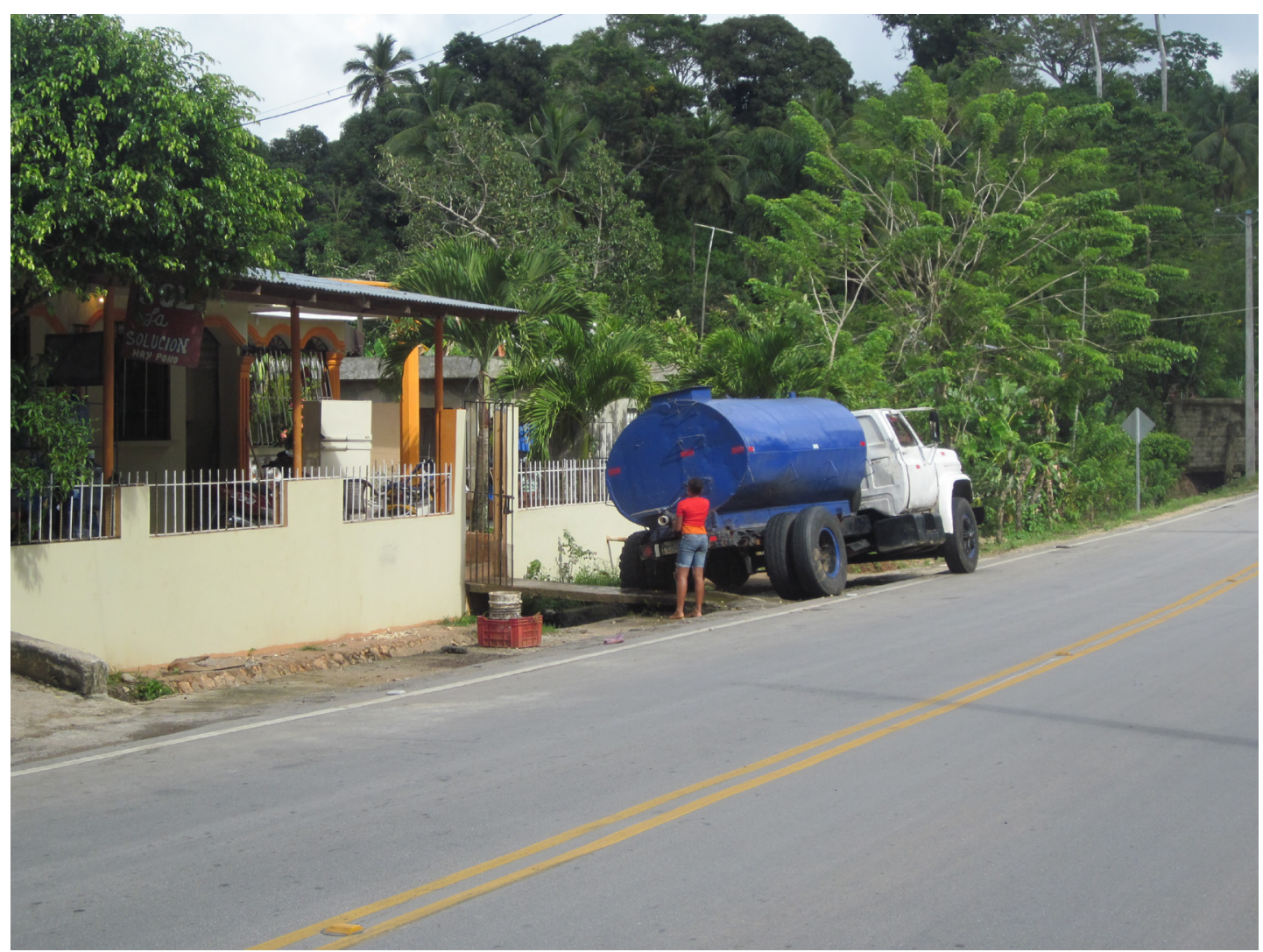

Figure 9: Water problems amidst lush vegetation in El Coyote, Samaná. Regular rainfall on the Samaná peninsula keeps fruit trees and other vegetation green, yet for lack of improved water Systems, residents regularly buy water from these tanker trucks 55 -gallons at a time to maintain their households.

No organized project for building RWH systems has been implemented by any institution in El Coyote. The PCV living in the community was interested in investigating the feasibility of investing in more formal RWH systems for this rainy community. Residents report that two attempts have been made to install a PWD system in El Coyote that would connect it to water sources and systems in other communities along the highway. The first attempt produced dirty water during one day of testing, never to work again, and the second was damaged before completion as a result of construction of the new highway.

Residents have interest in connecting to a new PWD system in the nearby community of Algarrobos or to the municipal water system of Samaná. The Algarrobos connection is $200 \mathrm{~m}$ away and $33 \mathrm{~m}$ downhill of El Coyote, whereas the Samaná pipeline is a few kilometers away, and 100m downhill (Google 2012). The water system for Algarrobos, despite being constructed within a year of the study and coming from a supposedly plentiful, clean source at a river's headwaters, only provides water to households every two to three days. Residents stated the reason was that the operator is not paid and thus cannot afford the time to manually operate the pumps daily. Connection of a new water system for El Coyote to the existing Algarrobos system will be referred to as option P-4. 
A large spring also enters a river from the ravine below the community and could be used to provide a community 'owned' source of water. This spring is a half kilometer away and fifty meters downhill and maintains discharge rates far in excess of the water needs of all households in El Coyote. A PWD system bringing water from this spring to El Coyote will be called option P-5 in this report. Both piped solutions for El Coyote would require pumping.

According to the PCV living in the community, prior to this study, residents of El Coyote held a 'huelga' or strike, closing the tourist highway running through the community as an attempt to pressure the government to take action on improving access to potable water. 


\section{Methods}

In order to achieve the objectives of this study (see Section 1.3), qualitative and quantitative data were collected. Land surveying was conducted and source spring discharge measurements were combined with population data and price quotes for materials to create preliminary engineering designs and budgets for piped water supply options in each community. Monthly rainfall data for the regions of the different communities was obtained from the Dominican National Office of Meteorology (ONAMET). Roof catchment areas and water storage containers were measured and counted throughout the communities.

At the same households where the engineering measurements were taken, community members were surveyed. The survey included thirty-four questions regarding current water use, preference for different sources of water, and preference and opinions of different options for improved water supply projects. The surveys provided insight into community member preferences towards domestic rainwater harvesting or piped water systems and more quantitative information about household water storage, the volume of water used over time in a household, the costs of carrying or buying water, and the duration of rainy seasons and droughts. This information was combined with or compared to rainfall data and measurements of roof catchment areas and storage containers to provide rainwater harvesting system designs (existing and proposed) and budgets.

Budgets and estimated water production from the different improved water system options were converted for comparison in terms of capital cost per liter per capita per day (\$US/lpcd). This straightforward engineer's cost-benefit comparison was placed in the social context of community members views towards their different options for improved water supply. The following sections describe the different methods used in more detail.

\subsection{Study Area}

The three communities chosen for the study shared the common goal of improving their water systems. They are communities in which RWH systems have been implemented or considered for further implementation as an alternative to PWD system projects. Implementation of PWD is considered expensive or otherwise challenging in the communities. Previous failed attempts to construct and maintain PWD projects in these communities are evidence of this. The geographic setting and current state of water supplies in the communities were summarized in Section 1.4.

Table 1 summarizes the water system improvement options considered in this study for each community. Agua de Luis and Los Derramaderos, because of their proximity and similarities are grouped together. 
Table 1: Summary of water system improvement options for study communities

\begin{tabular}{|c|c|c|}
\hline Characteristic & El Coyote, Samaná & $\begin{array}{l}\text { Agua de Luis \& Los } \\
\text { Derramaderos, Montecristi }\end{array}$ \\
\hline Precipitation & Wet $(2,199 \mathrm{~mm} /$ year $)$ & Dry (759 mm/year) \\
\hline $\begin{array}{l}\text { Previous NGO investment in } \\
\text { RWH Systems }\end{array}$ & No & Yes \\
\hline $\begin{array}{l}\text { Potential for RWH System } \\
\text { Investment }\end{array}$ & Yes & Yes \\
\hline $\begin{array}{l}\text { Potential for connection to } \\
\text { existing government-built piped } \\
\text { water system requiring pumps }\end{array}$ & Yes $_{[\text {Algarrobos }]^{1}(\mathrm{P}-4)^{2}}$ & Yes [Hatillo Palma] ${ }^{1}$ (P-1) \\
\hline Potential for spring-fed GFWS & No & $\mathrm{Yes}^{3}(\mathrm{P}-2),(\mathrm{P}-3)$ \\
\hline $\begin{array}{l}\text { Potential for spring-fed piped } \\
\text { water system requiring pumps }\end{array}$ & Yes (P-5) & No \\
\hline
\end{tabular}

${ }^{\mathrm{T}}$ Existing system in parentheses.

${ }^{2}$ Codes in parentheses indicate different piped water system options.

${ }^{3}$ GFWS could serve either Los Derramaderos and Agua de Luis (P-2) or Los Derramaderos (P-3).

The household survey described in section 2.5 was designed to obtain residents opinions of RWH and piped water system options, while the design and budgets prepared as described in section 2.6 considered the options' feasibility and cost from an engineering standpoint. Because of the distance of the springs in Los Derramaderos from Agua de Luis, as well as their observed output, option (P-2) serving Agua de Luis in the Los Derramaderos GFWS was not included in household survey questions. Testing of the survey questionnaire indicated this to be an unpopular and unlikely option among the residents of Agua de Luis and Los Derramaderos. A budget calculation was made for a GFWS that could serve both communities (P-2) in Montecristi with a lower design demand flow, despite community concerns about there being too little water.

\subsection{Land Surveying}

Land surveys were conducted using two methods. For the communities of Los Derramaderos and Agua de Luis, all measurements were taken using a simple Garmin Etrex ${ }^{\circledR}$ handheld GPS device. Waypoints were recorded at locations that would be critical to pipeline design including turns, high and low elevations, intersections, water source, water storage tank location, and terminal points in the community. Waypoint information was downloaded or transcribed from the GPS device for later plotting and calculations with Microsoft ${ }^{\circledR}$ Excel and AutoCAD ${ }^{\circledR}$ programs.

In El Coyote, GPS was used to mark waypoints to map potential water system routes, but GPS data was supplemented with measurements taken using a handheld Abney Level and measuring tape. The Abney level has the advantage over GPS of being able to record accurate elevation changes, especially in areas of high foliage cover (like that found in the river valley where the spring source is located). Angles and distances were measured with the Abney Level and elevation change was calculated using the methods described in Sections 3.3 and 3.4 of 'Design of Potable Water Supply 
Systems in Rural Honduras (Reents 2003). It was determined that the most accurate representation of the stretch from the spring to the road in El Coyote was given by the Abney Level, thus, distances and elevations used for hydraulic design for this portion were from the Abney Level. Everywhere else, GPS data was used.

The Abney level was used in El Coyote to measure distance and elevation change along the route between the water source and the highway along which the community was located. The Abney level was used to measure distance and elevation from the route intersection on the road, through the community to a possible site for a water tank. This route was later measured with the GPS device.

GPS waypoints were recorded for all households surveyed (see Sections $2.4 \& 2.5$ ). GPS data measured in degrees latitude and longitude was converted to Universal Transverse Mercator (UTM) coordinates applying the WGS 84 datum in the Excel based UTM Converter from the University of Wisconsin (Dutch 2005).

Land survey data collected can be found in Appendix D.

\subsection{Monthly Rainfall Data}

The three small, rural communities being studied did not have meteorological stations within them, nor did the timeframe of the study allow for collection of precipitation data on site. Rainfall data for towns near the study sites was available through the website of the National Office of Meteorology (ONAMET). Monthly-accumulated precipitation for 2011 and the average monthly precipitation $\left(\mathrm{P}_{\mathrm{M}}\right)$ was obtained for the towns of nearby Villa Vasquéz and Samaná (Meteorología 2011). Precipitation data is found in Appendix B. See Figure 7 for locations of the meteorological stations.

\subsection{Roof Catchment Area and Water Storage Container Measurements}

To measure current and potential capacity for rainwater harvesting, roof catchment area was measured at each surveyed household. The most common roofing surfaces are corrugated zinc, poured concrete, and thatch. Zinc and concrete roofing areas were measured, as these are both commonly used to collect rainwater. As described in Martin (2009), thatch or other lesser roofing materials were not included because they are less efficient catchment surfaces and may provide lower quality water. Prior to making measurements, a walk-around was performed to sketch roof areas and water storage containers at each household. The dimensions of roofs were measured with a plastic tape. By analyzing rooflines and gutter placement, measurements and notes were taken to indicate what roof area was being used for catchment as well as unused

roof area. Survey responses were combined with visual inspections and measurements of water storage containers to make an inventory of water storage at each household. Storage container types and volumes are regularly repeated in the communities, so in most cases no measurements had to be made. Unlike in Martin (2009), open barrels and large buckets were included in the survey, as these are regularly used storage containers that often maintain sufficient water quality for intended uses.

Roofline measurements were rounded to the nearest ten centimeters for ease of measurement and recording. Overhang of the eaves on each house was included in the 
measurements, although this incurs some human error, since the tape must be placed where the eave visually appears to end. In Figure 10, a birds-eye view sketch is shown of a home in Los Derramaderos with a RWH system. Sketches of all homes surveyed are available in Appendix C. Areas in blue represent roof area from which water is captured by conduits and sent to either the cistern or a barrel. Areas in yellow have no conduits, and are considered unused roof area for RWH.

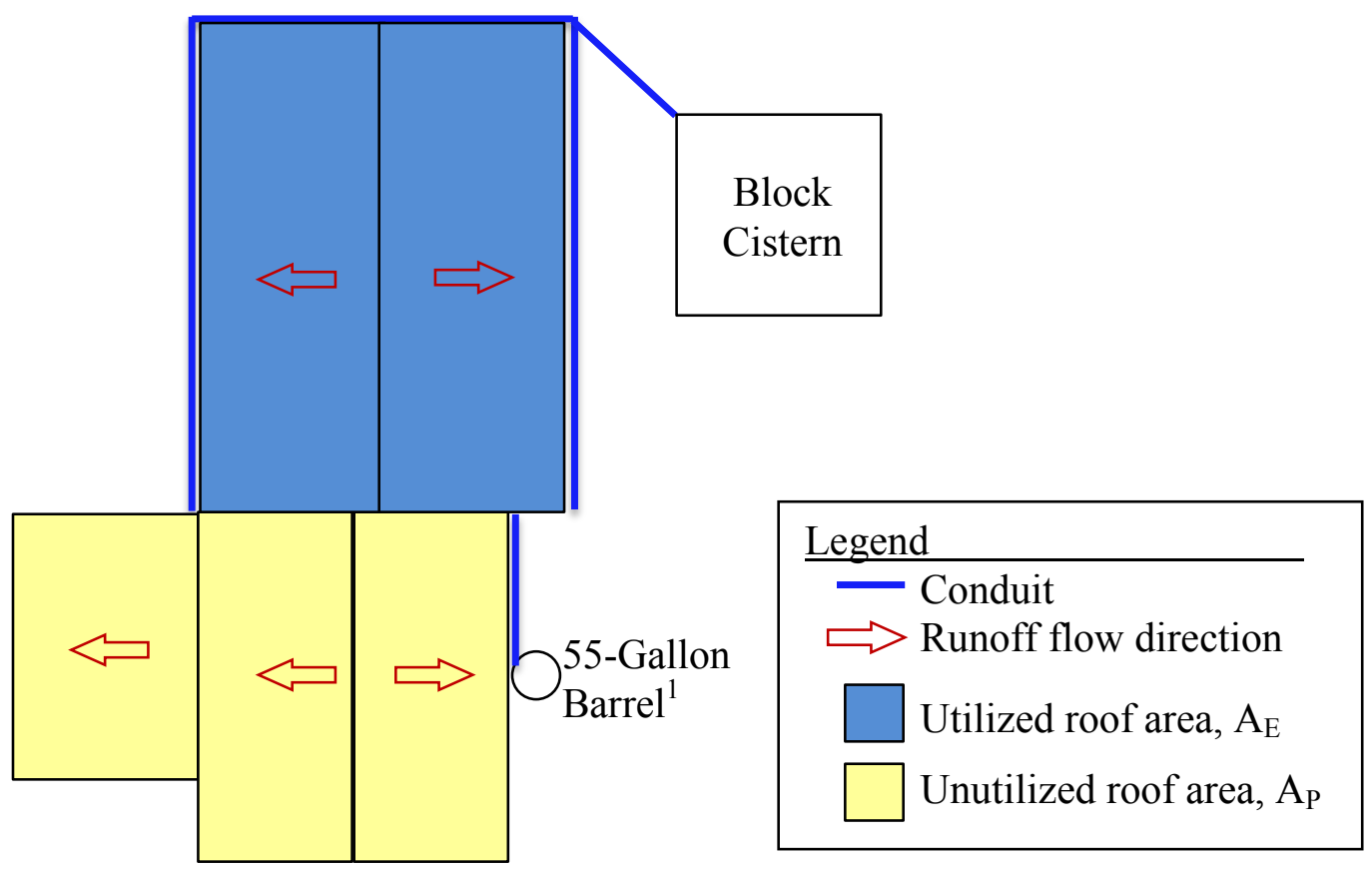

Figure 10: Example sketch of a RWH system in Los Derramaderos. ${ }^{1}$ Representations of storage containers are not to scale.

\subsection{Household Survey}

A household survey was designed and submitted to the Michigan Technological University Internal Review Board and received an Exempt Approval, MO825E, on November 2, 2011. During survey design, the questions were tested in multiple homes in all study communities. Revisions were made based on these tests and recommendations from local Dominicans, Volunteers serving in the communities, and engineering and Spanish language faculty at Michigan Tech. The survey was prepared simultaneously in Spanish and English, and checked with each revision for continuity between the translations. The Survey Protocol (Appendix A) describes how the survey was administered and includes the full text of the consent statement and survey questions in English and Spanish.

Time did not allow for surveying all households in the community. In order to obtain a spatially representative sampling of households, the author discussed the layout and distribution of homes in a community with the resident Volunteer before beginning surveys. Having identified sectors and extents of the communities, the author walked down the street and surveyed every second or third house, switching from one sector to the next on each day. The survey was administered in 106 total households between 
the three communities. The total number of households in the communities is estimated to be 416 . The survey consisted of 34 questions divided into four sections. The full survey and consent form are found in Appendix A.

\section{A. Consent to Participate (Questions 1-4)}

The consent to participate explained the purpose of the study and the respondent's freedom to participate if so desired. Respondents were told during the orally read consent statement that they were welcome to provide additional ideas or ask questions. The purpose of the report as an academic study and thus not directly bearing on the implementation of any actual water project was also explained. The consent form questions also determined if the respondent was a head of household and if he or she were an adult.

\section{B. Demographics (Questions 5-13)}

Demographic information collected includes age, number of people in the household, occupation, income or expenditures, education level of the respondent, and if the household had family members living in large Dominican cities or abroad.

\section{Current Water Sources (Questions 14-21)}

Before looking forward to options for improving water systems, this section posed questions determining the current status of each household's water resources. These questions determined what water sources are used for potable water needs (drinking and cooking) and other household water needs such as washing, bathing, and cleaning. Categories of water sources included:

$\square$ Water collected or carried from remote locations

$\square$ Rainwater harvesting and from roof catchment

$\square$ Piped water system

Purchased water

Treated water

Treated water was not an independent source on its own, but if the respondent mentioned that they treated water and how, it was noted. Questions 14-17 led the surveyor and the respondent into a discussion about their different water sources and systems. Costs, such as the price of a 5-gallon jug of bottled water or the time required to collect water from a well were recorded. When possible, the respondent estimated for how many months per year that they relied on each water source. For instance, a household may pass seven months using captured rainwater and five months buying water from a tanker-truck. Types of rainwater harvesting gutters used and the numbers, types, volumes, and costs of water storage containers were inventoried (q.18).

Question 19 required the respondent to estimate how long the total water storage volume they had in their household would last without rain or other inputs of water. For questions 20 and 21, respondents talked about changes in water sources and water resources over the years. 


\section{Water Preferences (Questions 22-34)}

The respondents were asked about their preferences for different sources of water for potable and other household uses. The topic was addressed first as an open-ended question to avoid leading the response (q. 22-25) and then approached with provided choices to be ranked (q. $26 \& 27$ ). Sources were ranked first according to potability and then by available volume and reliability.

After discussing their preferences for sources of water, respondents were asked "In your opinion, how could your household's and your community's water resources be best improved? (q. 28)" Then, specific water system improvement options were ranked first "according to potential impact on household water use considering quality and availability (q. 29)" and according to the monetary cost the respondent perceived each project would have (q. 30). In questions that required rankings, if the respondent had mentioned a source or water system improvement other than the provided options in their initial open-ended response, this option was added to the ranking choices for that respondent.

Question 31 sought the respondent's opinion of harvested rainwater for drinking (q. 31). Then respondents were asked if it was worthwhile to begin or improve rainwater harvesting projects (q. 32) and if it was worthwhile to repair or begin new construction of a piped water system project in the community (q. 33). The questioning probed further, asking why they considered these improvements worthwhile or not; if the respondent had shown clear preferences, they were asked about the most important benefits or advantages of their preferred solution. Finally, respondents were asked if they had other information or questions they wanted to share. This concluded the household survey.

\subsection{Design and budget calculations}

The purpose of engineering design and budget calculations was to estimate capital construction costs of the different water system improvement options considered. The design population served by each option was calculated using the number of households in each community (provided by resident PCVs) and the average household size reported in the surveys conducted in the community. None of the options consider future population growth in the community, since it is impossible to implement an RWH project that builds systems for unconstructed homes. Design calculations were made to ensure that the proposed systems could feasibly produce specified water service thresholds (as lpcd), and provide sufficient information about materials to create a preliminary budget. If the systems were to be constructed, more detailed design work would be needed.

For RWH systems, only the construction or purchase cost of storage volume was included. Gutters for conveyance of rainwater from the roof to storage containers are assumed an insignificant cost and have not been included in the estimated costs. For PWD systems, budgeted components include intake works, water storage tank, break pressure tanks, pipes for transmission and distribution, tap stands, stream crossings, and pump stations. A safety factor of $15 \%$ has been added to the budget for each PWD system to account for fittings, valves, or electrical components required in the 
pipeline and pump stations but not specified in the preliminary design. The absence of conduit from the RWH system budgets and the addition of the $15 \%$ safety factor to PWD system budgets is an intentional effort to create a best case scenario for RWH when comparing its costs to those of piped water distribution systems.

Labor (skilled or unskilled), operation, maintenance and repair costs are not considered in budget calculations. These costs could include, but are not limited to electricity costs for pumping, replacement of broken pipes or gutters, and repair of leaking RWH storage containers. These are significant costs for all system options, but are assumed to be paid for by the users over the lifetime of each system. In the author's experience working with Peace Corps, these costs would be considered part of the 'community contribution' to a project. A high community contribution during initial planning and construction is expected to result in continued contribution from the community during operation and maintenance.

Rainwater Harvesting System Design RWH storage container volume was calculated with a water balance analysis that incorporated monthly rainfall data (Section 2.3) with roof catchment areas (Section 2.4). Calculations were made per capita for the households sampled by dividing each household's roof catchment area and storage container volume (existing or designed) by the number of people reported as living in the home. The annual and monthly potential rainwater supply was calculated as follows for both existing and total potential roof catchment area scenarios. A best case scenario was assumed with a runoff coefficient of 1 , indicating a $100 \%$ efficient catchment and collection system. Well-constructed RWH systems with corrugated 'zinc' iron roofing and functioning gutters may obtain C values of 0.9 or greater, however, a "long term" operational C value of 0.8 is recommended (Gould and Nissen-Petersen 1999).

$\mathrm{P}_{\mathrm{M}}=$ Monthly average precipitation $(\mathrm{m})$

$\mathrm{P}_{\mathrm{A}}=$ Average annual precipitation $(\mathrm{m})$

$A_{E}=$ Existing roof catchment area utilized $\left(\mathrm{m}^{2}\right)$ (See Figure 10)

$A_{P}=$ Potential roof catchment area currently unutilized $\left(\mathrm{m}^{2}\right)($ See Figure 10$)$

$A_{T}=$ Total roof catchment area $=A_{E}+A_{P}\left(m^{2}\right)$

$\mathrm{C}=$ Runnoff coeficient (Volume runnoff collected/Volume rainwater hitting roof)

$\mathrm{R}_{\mathrm{A}, \mathrm{E} \text { or } \mathrm{T}}=$ Annual potential rainwater supply $=\mathrm{P}_{\mathrm{A}} * \mathrm{~A}_{\mathrm{E} \text { or } \mathrm{T}} * \mathrm{C}\left(\mathrm{m}^{3}\right)$

$\mathrm{R}_{\mathrm{M}, \mathrm{E} \text { or } \mathrm{T}}=$ Monthly potential rainwater supply $=\mathrm{P}_{\mathrm{M}}{ }^{*} \mathrm{~A}_{\mathrm{E} \text { or } \mathrm{T}} * \mathrm{C} \quad\left(\mathrm{m}^{3}\right)$

Per capita water demand thresholds were defined as follows.

$\mathrm{D}_{\mathrm{d}}=$ Daily water demand (liters / capita / day) (lpcd)

$\mathrm{D}_{\mathrm{M}}=$ Monthly water demand $\left(\mathrm{m}^{3} /\right.$ capita $/$ month $)$

$\mathrm{D}_{\mathrm{A}}=$ Annual water demand $\left(\mathrm{m}^{3} /\right.$ capita $/$ year $)$

RWH system improvement options were evaluated first by comparing the annual potential rainwater supply $\left(\mathrm{R}_{\mathrm{A}}\right)$ with the annual water demand $\left(\mathrm{D}_{\mathrm{A}}\right)$. 
If $\mathrm{R}_{\mathrm{A}} \geq \mathrm{D}_{\mathrm{A}} \rightarrow \mathrm{RWH}$ System may be feasible.

If $R_{A}<D_{A} \rightarrow$ RWH System is not feasible.

This determined whether or not roof catchment area was sufficient to meet a given demand threshold given annual total precipitation and assuming that all water collected from the roof during the year could be used or stored until use. Thus, it does not consider water storage container volume. The volume of storage containers, both existing and potential future volume, was evaluated throughout the year on a monthly basis. The following algorithm was run for twelve months, beginning in January.

$\mathrm{S}_{\mathrm{m}}=$ Stored water at end of current month, $\mathrm{m}\left(\mathrm{m}^{3}\right)$

$\mathrm{S}_{\mathrm{m}-1}=$ Stored water at end of previous month $\left(\mathrm{m}^{3}\right)$

$\mathrm{T}=$ Per capita water storage container volume $\left(\mathrm{m}^{3}\right)$

$\mathrm{S}_{\mathrm{m}}$ was calculated as follows for the month of January:

If $\mathrm{T}>\mathrm{D}_{\mathrm{M}} \rightarrow \mathrm{S}_{\mathrm{m}}=\min \left(\mathrm{R}_{\mathrm{M}}, \mathrm{T}\right)$.

If not:

If $\mathrm{T}+\mathrm{R}_{\mathrm{M}}-\mathrm{D}_{\mathrm{M}}<0 \rightarrow \mathrm{S}_{\mathrm{m}}=0$

If not:

$\mathrm{S}_{\mathrm{m}}=\min \left(\mathrm{T}+\mathrm{R}_{\mathrm{M}}-\mathrm{D}_{\mathrm{M}}, \mathrm{T}\right)$

This algorithm assumes that January's water needs were met by a best case combination of stored water from December and January rainfall. The amount of water stored at the end of the month depends on the storage container capacity and the rainfall for the month. December water stored for January use could reach but not surpass monthly demand, limited by water storage container capacity.

The stored water for each of the remaining eleven months' was calculated as follows: Available water exceeds demand and storage capacity:

If $\mathrm{S}_{\mathrm{m}-1}+\mathrm{R}_{\mathrm{M}}-\mathrm{D}_{\mathrm{M}} \geq \mathrm{T} \rightarrow \mathrm{S}_{\mathrm{m}}=\mathrm{T}$

Available water does not meet demand:

If $\mathrm{S}_{\mathrm{m}-1}+\mathrm{R}_{\mathrm{M}}-\mathrm{D}_{\mathrm{M}} \leq 0 \rightarrow \mathrm{S}_{\mathrm{m}}=0$

Available water meets demand but does not exceed storage capacity:

If $0<\mathrm{S}_{\mathrm{m}-1}+\mathrm{R}_{\mathrm{M}}-\mathrm{D}_{\mathrm{M}}<\mathrm{T} \rightarrow \mathrm{S}_{\mathrm{m}}=\mathrm{S}_{\mathrm{m}-1}+\mathrm{R}_{\mathrm{M}}-\mathrm{D}_{\mathrm{M}}$

To be considered feasible, a RWH System configuration must yield $\mathrm{S}_{\mathrm{m}}$ values greater than zero for all twelve months at the given demand threshold. A calculation of stored water $\left(\mathrm{S}_{\mathrm{m}}\right)$ reported as zero indicated that previously stored water and the month's rainwater captured were insufficient to meet demand and the household ran out of water.

The households were first evaluated using the storage container volume (T) measured in the survey process. For households surveyed in a community with an annual potential rainwater supply $\left(\mathrm{R}_{\mathrm{A}}\right)$ value sufficient to meet annual demand, the algorithm 
was used to determine at what storage container volume, $\mathrm{T}$, specified demand thresholds could be met throughout the entire year. $T$ was defined by multiplying the monthly per capita demand by an assumed number of people per household.

$\mathrm{H}_{\mathrm{a}}=$ Average or assumed household size in a community

$\mathrm{H}_{\mathrm{s}}=$ specific household size

$$
\mathrm{T}=\mathrm{D}_{\mathrm{M}} * \mathrm{H}_{\mathrm{a}} / \mathrm{H}_{\mathrm{s}}
$$

$\mathrm{H}_{\mathrm{a}}$ was adjusted until all households with a sufficient $\mathrm{R}_{\mathrm{A}}$ were able to maintain water stored $\left(\mathrm{S}_{\mathrm{m}}\right)$ greater than zero for all twelve months. This defined the household water storage container volume $\left(=\mathrm{D}_{\mathrm{M}} * \mathrm{P}_{\mathrm{a}}\right)$ for each community that would be needed for an RWH System to be feasible at a given demand threshold.

A limitation of the algorithm is that it can only calculate water balance on a monthly basis. For household storage volumes less than monthly demand volume, the algorithm inaccurately portrays the capabilities of RWH, since intra-month variability is not considered. Residents claim that droughts of one month or longer can be expected at least every two or three years in all study sites. This is supported by Figure 11 that shows average monthly rainfall and its standard deviation from year to year. For both of these reasons, the design volume of storage containers considered was set at a minimum of one month of demand for an average sized household.

Container volumes calculated as sufficient to allow RWH to meet defined demand thresholds were input into the spreadsheet E-fc-tank.xlsx (Appendix E) to estimate materials needed for the construction of a ferro-cement tank of the defined volume. This spreadsheet was created by Peace Corps Volunteers in the Dominican Republic who regularly use it to budget and purchase materials for the construction of ferrocement tanks. Price quotes for quantities of materials calculated for each tank volume were used to estimate the preliminary budgets found in APPENDIX F.

\section{Piped Distribution System Design}

The five piped distribution system projects described in Section 2.1 were considered as feasible options and were designed to create an estimated budget for each. Two of these designs are for gravity-fed water systems; three systems would require pumping. Three systems rely on local springs within the community as the source of water; two systems would connect to an existing piped distribution system in another community as a water source. A design and preliminary budget was prepared for each system using the following design information and assumptions commonly used by the author and other Water/Sanitation Volunteers who served with PCDR.

\section{Design calculations}

PVC Pipes for transmission and distribution of water comprise the largest materials budget component for every piped distribution system being considered. Hydraulic design of pipelines was carried out according to the principles found in "A Handbook of Gravity -Flow Water Systems" (Jordan 2006) using the land survey data collected. Major head loss due to friction in pipes was calculated by referencing the table "Rigid PVC Frictional Headloss Factors" (Faiia 1982). All pipelines were designed within 
the working pressure limits of the specified pipes. Calculations and hydraulic grade line charts can be found in Appendix D.

The design population for each system was calculated by multiplying the number of households in the community (provided by PCVs living in the community) by the average number of people per household determined in the survey $\left(\mathrm{H}_{\mathrm{a}}\right)$. This population was multiplied by the specified per capita water demand threshold $\left(D_{d}\right)$ to calculate an average daily demand flow.

Water storage tanks to feed the distribution system were designed to store a volume equivalent to one day's worth of demand. Materials needed for these tanks were estimated using E-fc-tank.xlsx (Appendix E). Pumps were selected using pump curves provided in manufacturer specifications (WICOR Industries 2003). Materials needed for stream crossings were estimated using the design tool, E-Puente.xlsx provided by PCDR (Appendix E). Materials needed for the intake works, break pressure tanks, and tap stands were estimated by the author using knowledge of their design gained while a PCV, and with principles and design drawings described by Jordan as well as in "The design, construction, and maintenance of a gravity-fed water system in the Dominican Republic" (Niskanen 2003).

\section{Design assumptions}

The following assumptions were made during the design of PWD systems:

- Peak water demand was calculated using a factor of four times average demand.

- Minor losses due to fittings in the piped water systems are insignificant and were not considered.

- Population will not increase. No growth factor was used for defining water demand. This allows comparison of RWH and PWD systems at precisely the demand threshold specified, and also is an acknowledgement that unlike PWD, RWH systems cannot be built for households that do not exist yet.

- Fittings such as valves and elbows as well as minor electrical parts for pumping not detailed in the budget were accounted for with a $15 \%$ safety factor applied to each project budget.

- Flows measured at spring sources with one time measurements are assumed to be maintained all year.

- For systems sourcing water from other distribution systems (Hatillo Palma and Algarrobos), it was assumed that these sources have a limitless quantity of water available, and that pressure head at the point of connection is zero.

\section{Materials Pricing}

Price quotes to calculate project budgets for all water system improvement options were acquired as follows. Price quotes for PVC pipes were acquired from Industrias Nacionales $\mathrm{C}$ por A (INCA). INCA is the largest producer of PVC pipes in the Dominican Republic. All other price quote used in preparing cost estimates for the different water systems were obtained from Ferreteria Bellon or Ferreteria Ochoa. Bellon and Ochoa are two of the largest hardware and building suppliers in the country. The author and fellow Volunteers maintain a strong relationship with sales staff at these companies. The majority of materials for Peace Corps' implemented 
water systems are purchased from these companies, as projects receive significant discounts on purchases and the staff is helpful when determining what materials are best to use. The majority of prices from INCA and Bellon were obtained in quotes dated February 24, 2012 and April 4, 2012, respectively. Pump prices were obtained from Ferreteria Ochoa on April 9, 2012. Aggregate and sand prices were obtained from local hardware store Hatillo Palma, Montecristi in October of 2011). The sources or dates of any other estimated or quoted prices are noted in Appendix F.

An exchange rate of 39.04753 Dominican Pesos per US Dollar from April 10, 2012 was used for all conversions of prices and costs throughout the study (ExchangeRates.org 2012). 


\section{Results and Discussion}

\subsection{Monthly Rainfall Data}

The average and 2011 monthly precipitation for meteorological stations near the study sites are plotted in Figure 11 and Figure 12 below. Precipitation data for the year 2011 is provided, since many responses in the household survey were made in reference to that year. The frequency of drought periods with little or no rain is of great concern to households attempting to rely on RWH as a primary water source, especially in communities in the drier Montecristi. Consideration of standard deviation from average monthly rainfall indicates that both Samaná and Villa Vasquéz regularly experience months of drought with no precipitation.

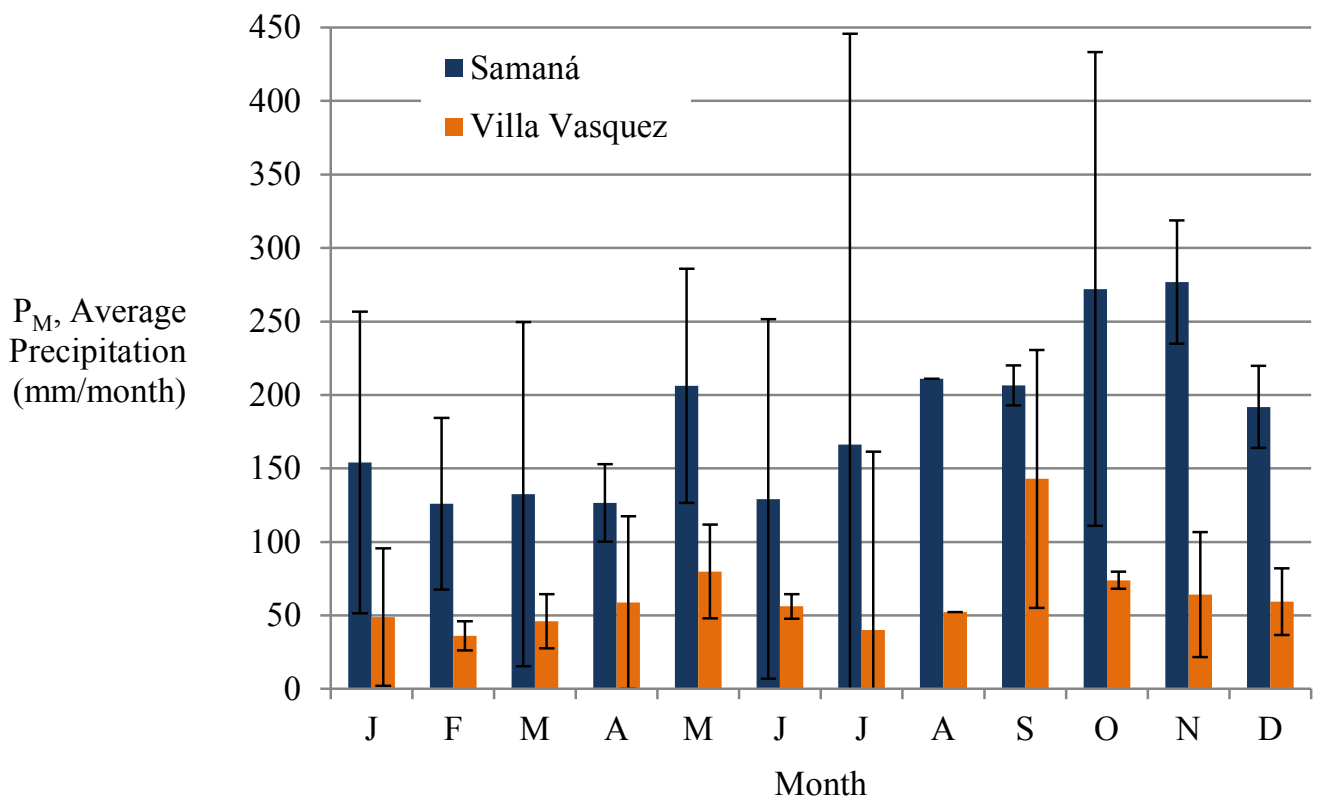

Figure 11: Average monthly precipitation from historical record provided by ONAMET at meteorological stations showing standard deviation. Error bars show one standard deviation from the average. No standard deviation was available for the month of August. 


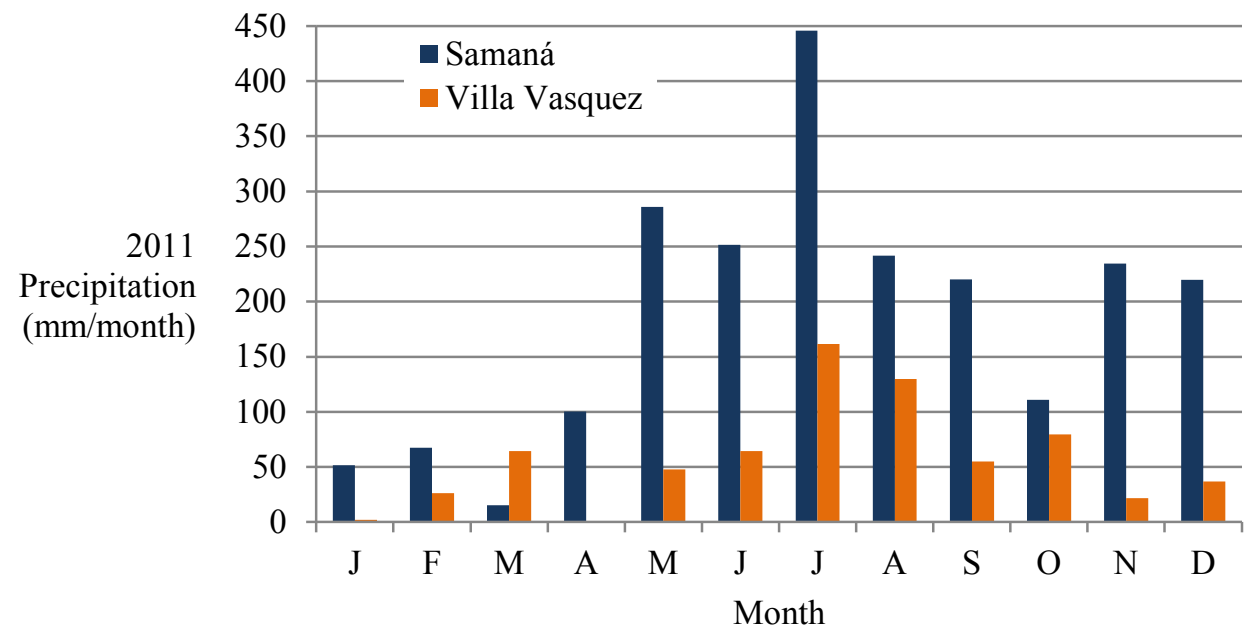

Figure 12: Monthly precipitation for 2011 provided by ONAMET at meteorological stations.

\subsection{Land Survey}

The following maps of the communities studied were prepared using GPS data collected. Elements shown on the maps include household survey location distribution, the path that water distribution lines might take throughout each community along the road, and the location and transmission route for different supply options for piped distribution systems.

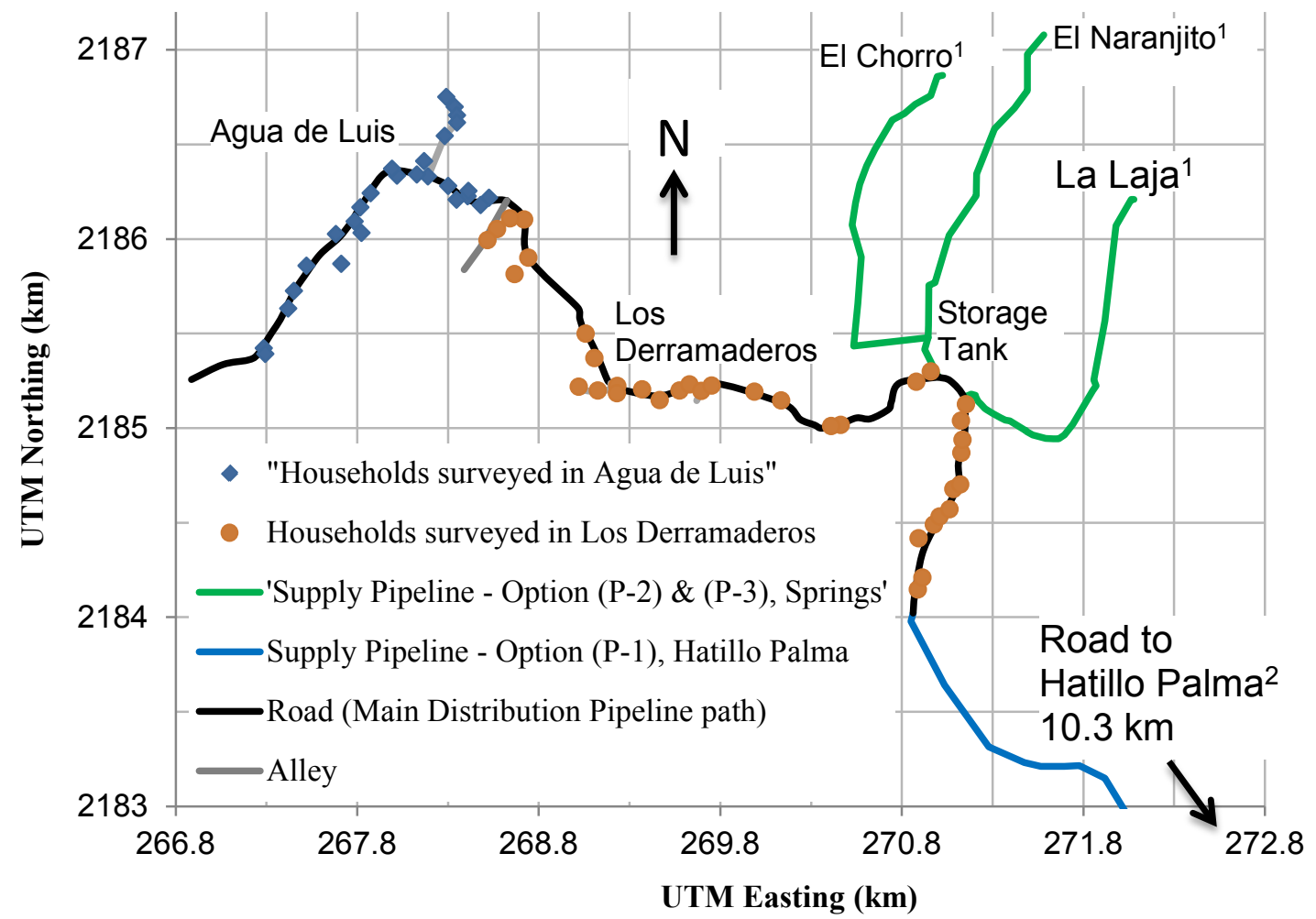

Figure 13: Land survey mapping: Agua de Luis and Los Derramaderos, Montecristi. Although households surveyed only are a fraction of the population, their location on the map does define the extent of the two communities. ${ }^{1}$ All three springs would be piped into the storage tank for either GFWS $(\mathrm{P}-2,3) .{ }^{2}$ After connecting to the system in Hatillo Palma (P-1), water could be pumped along the road and into the storage tank. 
The three spring sources in Los Derramaderos are located above the community on a mountain ridge set back from the north side of the road. The town of Hatillo Palma (and the regional piped water system) is lower in elevation than Los Derramaderos and Agua de Luis.

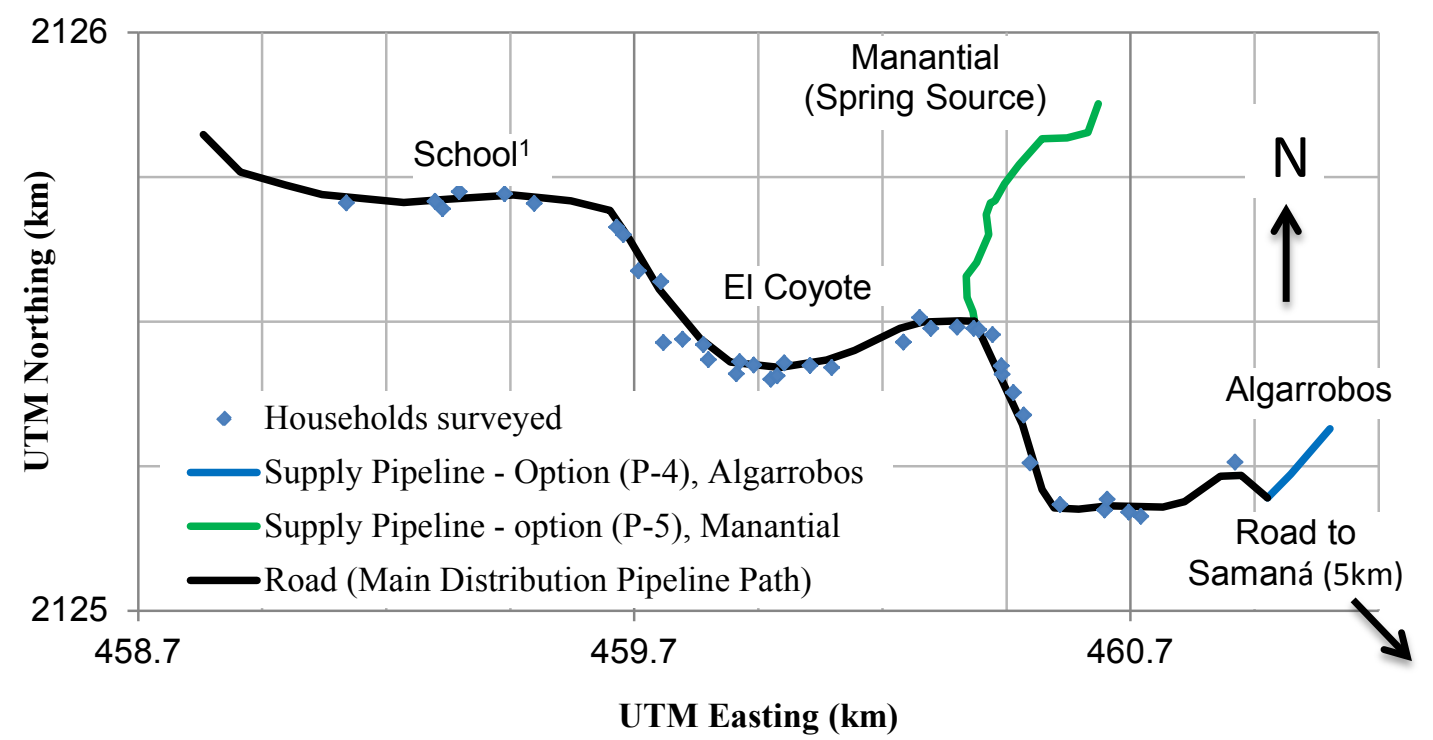

Figure 14: Land survey mapping: El Coyote, Samaná. ${ }^{1}$ The water tank for distribution system would be placed near the school with water pumped to it through the distribution system from either source.

The spring enters a riverbed below El Coyote. The paved road running through El Coyote is perched upon a ridge, with steep slopes on either side. In nearby Algarrobos, a recently completed distribution system reaches the point where the blue line begins. This potential source is also downhill from the highway and El Coyote. The Highest elevations are found near the school and further east, and would be the best locations for building a water storage tank for a distribution system.

\subsection{Household Survey}

The full range of the household survey questions and their translated responses are too broad to be presented here. Responses reported in quotations are paraphrased or were interpreted by the author as representative of the original responses. For all responses and raw data, see Appendix G. The following information combines and simplifies the most critical aspects of the responses.

\section{Demographics}

Responses to the first 13 questions of the survey about the demographics of the respondents and their households are summarized in Table 2 and Table 3. 
Table 2: Summary of responses to demographic questions (q. 1-12)

\begin{tabular}{|c|c|c|c|c|c|c|c|c|}
\hline & \multicolumn{2}{|c|}{ Overall } & \multicolumn{2}{|c|}{ Agua de Luis } & \multicolumn{2}{|c|}{ Los Derramaderos } & \multicolumn{2}{|c|}{ El Coyote } \\
\hline & \# & $\%$ & \# & $\%$ & \# & $\%$ & \# & $\%$ \\
\hline Head of Household: & \multicolumn{2}{|c|}{$\mathrm{n}=106$} & \multicolumn{2}{|c|}{$\mathrm{n}=29$} & \multicolumn{2}{|c|}{$\mathrm{n}=37$} & \multicolumn{2}{|c|}{$\mathrm{n}=40$} \\
\hline Yes & 100 & $94 \%$ & 29 & $100 \%$ & 35 & $95 \%$ & 36 & $90 \%$ \\
\hline No & 6 & $6 \%$ & 0 & $0 \%$ & 2 & $5 \%$ & 4 & $10 \%$ \\
\hline Gender: & \multicolumn{2}{|c|}{$\mathrm{n}=119$} & \multicolumn{2}{|c|}{$\mathrm{n}=33$} & \multicolumn{2}{|c|}{$\mathrm{n}=41$} & \multicolumn{2}{|c|}{$\mathrm{n}=45$} \\
\hline Male & 44 & $37 \%$ & 13 & $39 \%$ & 14 & $34 \%$ & 17 & $38 \%$ \\
\hline Female & 75 & $63 \%$ & 20 & $61 \%$ & 27 & $66 \%$ & 28 & $62 \%$ \\
\hline Age of respondents: & \multicolumn{2}{|c|}{$\mathrm{n}=119$} & \multicolumn{2}{|c|}{$\mathrm{n}=33$} & \multicolumn{2}{|c|}{$\mathrm{n}=41$} & \multicolumn{2}{|c|}{$\mathrm{n}=45$} \\
\hline Mean (years) & \multicolumn{2}{|c|}{50} & \multicolumn{2}{|c|}{48} & \multicolumn{2}{|l|}{50} & \multicolumn{2}{|c|}{52} \\
\hline Median (years) & \multicolumn{2}{|l|}{48} & \multicolumn{2}{|l|}{42} & \multicolumn{2}{|l|}{48} & 53 & \\
\hline Standard Dev. (years) & 17 & & 16 & & 18 & & 18 & \\
\hline Years living in community: & & 106 & & $=29$ & & & & 40 \\
\hline $0-5 Y r s$ & 6 & $6 \%$ & 4 & $14 \%$ & 1 & $3 \%$ & 1 & $3 \%$ \\
\hline$>6 y r s$ & 38 & $36 \%$ & 10 & $34 \%$ & 8 & $22 \%$ & 20 & $50 \%$ \\
\hline Whole life & 62 & $58 \%$ & 15 & $52 \%$ & 28 & $76 \%$ & 19 & $48 \%$ \\
\hline Sample population: & & 106 & & $=29$ & & & & 40 \\
\hline All homes & 494 & & 133 & & 159 & & 202 & \\
\hline Adults & 306 & $62 \%$ & 81 & $61 \%$ & 97 & $61 \%$ & 128 & $63 \%$ \\
\hline Minors $(<18$ yrs $)$ & 188 & $38 \%$ & 52 & $39 \%$ & 62 & $39 \%$ & 74 & $37 \%$ \\
\hline Household size: & & 106 & & $=29$ & & & & 40 \\
\hline Mean & 4.7 & & 4.6 & & 4.3 & & 5.1 & \\
\hline Median & 4 & & 4.0 & & 4.0 & & 5.0 & \\
\hline Standard Deviation & 2.1 & & 2.2 & & 1.7 & & 2.3 & \\
\hline Source of livelihood ${ }^{1}$ : & & 106 & & $=32$ & & & & \\
\hline Agriculture & 60 & $57 \%$ & 12 & $38 \%$ & 16 & $47 \%$ & 32 & $80 \%$ \\
\hline Tobacco & 12 & $11 \%$ & 7 & $22 \%$ & 5 & $15 \%$ & 0 & $0 \%$ \\
\hline Cattle/Cows & 21 & $20 \%$ & 10 & $31 \%$ & 11 & $32 \%$ & 0 & $0 \%$ \\
\hline Salary & 7 & $7 \%$ & 2 & $6 \%$ & 2 & $6 \%$ & 3 & $8 \%$ \\
\hline Industry \& Services & 32 & $30 \%$ & 7 & $22 \%$ & 10 & $29 \%$ & 15 & $38 \%$ \\
\hline Maintained by family & 19 & $18 \%$ & 6 & $19 \%$ & 8 & $24 \%$ & 5 & $13 \%$ \\
\hline Other & 2 & $2 \%$ & 0 & $0 \%$ & 0 & $0 \%$ & 2 & $5 \%$ \\
\hline Estimated household expenses ${ }^{2}$ : & & 104 & & $=28$ & & & & \\
\hline $0-5 k$ pesos/month & 28 & $27 \%$ & 8 & $29 \%$ & 9 & $24 \%$ & 11 & $28 \%$ \\
\hline 5-10k pesos/month & 54 & $52 \%$ & 16 & $57 \%$ & 20 & $54 \%$ & 18 & $46 \%$ \\
\hline $10-20 \mathrm{kpesos} / \mathrm{month}$ & 21 & $20 \%$ & 3 & $11 \%$ & 8 & $22 \%$ & 10 & $26 \%$ \\
\hline $20-50 \mathrm{k}$ pesos/month & 0 & $0 \%$ & 0 & $0 \%$ & 0 & $0 \%$ & 0 & $0 \%$ \\
\hline $50+k$ pesos $/$ month & 1 & $1 \%$ & 1 & $4 \%$ & 0 & $0 \%$ & 0 & $0 \%$ \\
\hline Respondent reported expenses & 68 & $65 \%$ & 10 & $36 \%$ & 21 & $57 \%$ & 37 & $95 \%$ \\
\hline Respondent reported income & 36 & $35 \%$ & 18 & $64 \%$ & 16 & $43 \%$ & 2 & $5 \%$ \\
\hline Immediate family: & & 106 & & $=29$ & & & & \\
\hline Family in large cities & 91 & $86 \%$ & 26 & $90 \%$ & 32 & $86 \%$ & 33 & $83 \%$ \\
\hline Family abroad & 58 & $55 \%$ & 19 & $66 \%$ & 29 & $78 \%$ & 10 & $25 \%$ \\
\hline City or Abroad & 99 & $93 \%$ & 28 & $97 \%$ & 37 & $100 \%$ & 34 & $85 \%$ \\
\hline
\end{tabular}

${ }^{1}$ Multiple responses were given by many people, thus the sum of percentage of population for all sources of livelihood mentioned is greater than $100 \%$.

${ }^{2}$ Respondents were given the option to estimate income OR expenses, reported here as equal. 
Table 3: Highest level of formal education level achieved by respondents (q. 12)

\begin{tabular}{rccccccccc} 
& $\begin{array}{c}\text { Overall } \\
(\mathrm{n}=106)\end{array}$ & $\begin{array}{c}\text { Agua de } \\
\text { Luis } \\
(\mathrm{n}=29)\end{array}$ & $\begin{array}{c}\text { Los } \\
\text { Derramaderos } \\
(\mathrm{n}=37)\end{array}$ & $\begin{array}{c}\text { El Coyote } \\
(\mathrm{n}=40)\end{array}$ \\
& $\#$ & $\%$ & $\#$ & $\%$ & $\#$ & $\%$ & $\#$ & $\%$ \\
\hline Formal education: & & & & & & & & \\
Did not attend school & 8 & $8 \%$ & 1 & $3 \%$ & 0 & $0 \%$ & 7 & $18 \%$ \\
4rth Grade or higher & 72 & $68 \%$ & 21 & $72 \%$ & 23 & $62 \%$ & 28 & $70 \%$ \\
8th Grade or higher & 45 & $42 \%$ & 11 & $38 \%$ & 15 & $41 \%$ & 19 & $48 \%$ \\
4rth Grade high school or higher & 26 & $25 \%$ & 7 & $24 \%$ & 10 & $27 \%$ & 28 & $70 \%$ \\
University with degree & 4 & $4 \%$ & 2 & $7 \%$ & 2 & $5 \%$ & 0 & $0 \%$
\end{tabular}

\section{Current Water Resources}

Survey responses indicated that household water management in all communities relies on multiple sources including RWH, purchased water (both from tanker trucks and bottled water), and water fetched from a variety of remote locations. Families may use one source for a certain use, they may mix water from different sources in storage containers, or they may alternate between sources depending on cost, changes in water quantity or quality with weather, or other factors. The focus of the results presented is to consider water systems improvements with RWH or piped distribution systems. It should be understood that where rainwater is shown to be insufficient of meeting water demand, in practice households supplement it with other sources of water that have their own associated costs. For instance, in Table 5, water storage containers are used for RWH but are also crucial as storage for purchased water or water brought on animal or on foot.

Table 4 includes the results of different questions that required residents to quantify aspects of their current water resources. Averages across the sample set in a community are presented, despite large variations amongst reported values. Variation can be attributed to both the inherent uncertainty caused by people estimating numbers they may not think of regularly, and by actual conditions and practices changing from household to household. The table is intended only to highlight basic similarities and differences from community to community for later comparison with other calculated results. None of the communities had functioning piped water systems, so this category went unused as a current water source.

When commenting on how and why their water resources had changed over the years (q. 20), nine respondents mentioned climate change as a reason. Especially in Montecristi, the author noted that residents associated continuing deforestation for the creation of pasture and crop land on mountain slopes with decreased rainfall and flow rates from springs. 
Table 4: Summary of current water resources indicators averaged by community. $\overline{\mathbf{X}}$ is the sample average and $\mathbf{S}$ is the sample standard deviation.

\begin{tabular}{|c|c|c|c|c|c|c|c|c|}
\hline & \multicolumn{3}{|c|}{$\underline{\text { Agua de Luis }}$} & \multicolumn{3}{|c|}{$\underline{\text { Los Derramaderos }}$} & \multicolumn{2}{|c|}{$\underline{\text { El Coyote }}$} \\
\hline & $\bar{x}$ & $\mathrm{~s}$ & $\mathrm{n}$ & $\bar{x}$ & $\mathrm{~S}$ & $\mathrm{n}$ & $\bar{x}$ & s $n$ \\
\hline \multicolumn{9}{|c|}{ Average months per year using water source ${ }^{1}$ : } \\
\hline RWH & 7.7 & 3.6 & 26 & 7.3 & 2.8 & 29 & 5.7 & 3.1 \\
\hline Fetched / carried & 8.9 & 4.1 & 9 & 4.8 & 4.3 & 5 & 7.2 & 3.6 \\
\hline Purchased & 5.3 & 3.7 & 20 & 4.5 & 2.7 & 25 & 5 & 2.8 \\
\hline
\end{tabular}

Average volume of water fetched daily (liters):

$\begin{array}{lccccccccc}\text { Per household } & \mathbf{1 2 8} & 75.9 & 12 & \mathbf{8 0} & 70 & 15 & \mathbf{9 8} & 68 & 42 \\ \text { Per capita }^{2} & \mathbf{2 8} & & 12 & \mathbf{1 9} & & & \mathbf{1 9} & & \end{array}$

Average cost per volume of purchased water (\$USD/100-liter):

$\begin{array}{lccccccccc}\text { Potable } & \mathbf{5 . 3} & 0.25 & 8 & \mathbf{5 . 1} & 1.3 & 13 & \mathbf{6 . 1} & 0.77 & 17 \\ \text { Non-potable }^{3} & \mathbf{0 . 1 9} & 0.08 & 22 & \mathbf{0 . 1 4} & 0.07 & 27 & \mathbf{0 . 8 9} & 0.08 & 27\end{array}$

Average duration of household storage (months) ${ }^{4}$ :$$
\begin{array}{llllllll}
4 & 25 & 3 & 2.2 & 33 & \mathbf{0 . 6} & 0.6 & 38
\end{array}
$$

${ }^{1}$ More than one source type is often used in a month. Not all respondents were able to estimate this value, and not all respondents use all three types of sources, thus the variation in sample size.

${ }^{2}$ Calculated by dividing household average by average household size for community

${ }^{3}$ Public subsidized vendor prices in Agua de Luis and Los Derramaderos; Private vendor price in El Coyote.

${ }^{4}$ The number of months water would last if all containers were filled and used until empty with no inputs.
}

Table 5: Average household water storage volume by community

Average household water storage (Liters)

\begin{tabular}{lccccc} 
Community: & $\begin{array}{c}\text { High volume } \\
\text { containers }\end{array}$ & $\begin{array}{c}\text { Low volume } \\
\text { containers }\end{array}$ & $\begin{array}{c}\text { All } \\
\text { containers }\end{array}$ & $\begin{array}{c}\text { per capita } \\
\text { volume }\end{array}$ & $\mathrm{n}$ \\
\hline Agua de Luis & 7852 & 425 & 8277 & 2242 & 32 \\
Los Derramaderos & 6862 & 754 & 7616 & 2045 & 34 \\
El Coyote & 964 & 726 & 1690 & 345 & 40 \\
\hline
\end{tabular}


In Table 5, high volume storage includes concrete water tanks and large plastic tanks (tinacos). Low volume includes 55 gallon barrels, 5 -gallon buckets and other small containers. Homes with no storage in a category are included in the average with a volume of zero liters. Outliers in the data set, such as a 48,000 liter cement block cistern constructed by one household in Agua de Luis, result in a high variation of the values. Low volume containers account for a much larger fraction of storage volume for RWH in El Coyote than they do in the Montecristi communities where $85 \%$ (n=66) of homes surveyed had at least one cement block tank constructed by the NGO PROLINO. The standard calculated useable volume of a PROLINO tank is 6,240 liters (although some were built larger), which coincides with the volume reported by respondents of a PROLINO cistern holding thirty 55-gallon barrels.

The roof catchment area for each home surveyed was measured as described in Section 2.4. Average household roof catchment areas are summarized in Table 6.

Table 6: Average roof catchment area by community. Total area $\left(A_{T}\right)$ is the sum of roof area utilized with existing gutters $\left(A_{E}\right)$ and roof area not in use for RWH but that could be utilized with additional gutters $\left(A_{P}\right)$. Figure 10 shows an example sketch of roof catchment area.

Average roof catchment area $\left(\mathrm{m}^{2}\right)$

\begin{tabular}{lccccc} 
Community: & $\begin{array}{c}\text { Area utilized } \\
\text { per home, } A_{E}\end{array}$ & $\begin{array}{c}\text { Area utilized } \\
\text { per capita }\end{array}$ & $\begin{array}{c}\text { Area available } \\
\text { per home, } A_{T}\end{array}$ & $\begin{array}{c}\text { Area available } \\
\text { per capita }\end{array}$ & n \\
\hline Agua de Luis & 61 & 17 & 94 & 25 & 29 \\
Los Derramaderos & 65 & 17 & 113 & 32 & 37 \\
El Coyote & 37 & 9 & 76 & 18 & 39 \\
\hline
\end{tabular}

Roof area utilized $\left(\mathrm{A}_{\mathrm{E}}\right)$ includes surfaces that drain to some form of conduit or collection point that leads to a storage container. Total roof catchment area $\left(\mathrm{A}_{T}\right)$ is the sum of utilized areas $\left(A_{E}\right)$ and other roof area that could be taken advantage of with the addition of gutters $\left(\mathrm{A}_{\mathrm{P}}\right)$. One factor that likely contributes to the higher roof area in the communities of Agua de Luis and Los Derramaderos is the number of households with family members living abroad, primarily in Venezuela. In such households, remittances from absent family members often go towards the construction of a second cement block residence. Often, the old family home and the newer one are both maintained.

The most basic analysis of RWH feasibility for the communities is to quantify the amount of rain hitting roof surfaces that could be collected. Figure 15 and Figure 16 show how many households could meet thresholds of per capita water demand $\left(D_{A}\right)$ with RWH given average monthly rainfall $\left(\mathrm{P}_{M}\right)$ and roof area utilized $\left(\mathrm{A}_{\mathrm{E}}\right)$, assuming that the annual potential rainwater supply generated $\left(\mathrm{R}_{\mathrm{A}}\right)$ can be used or stored until use. 


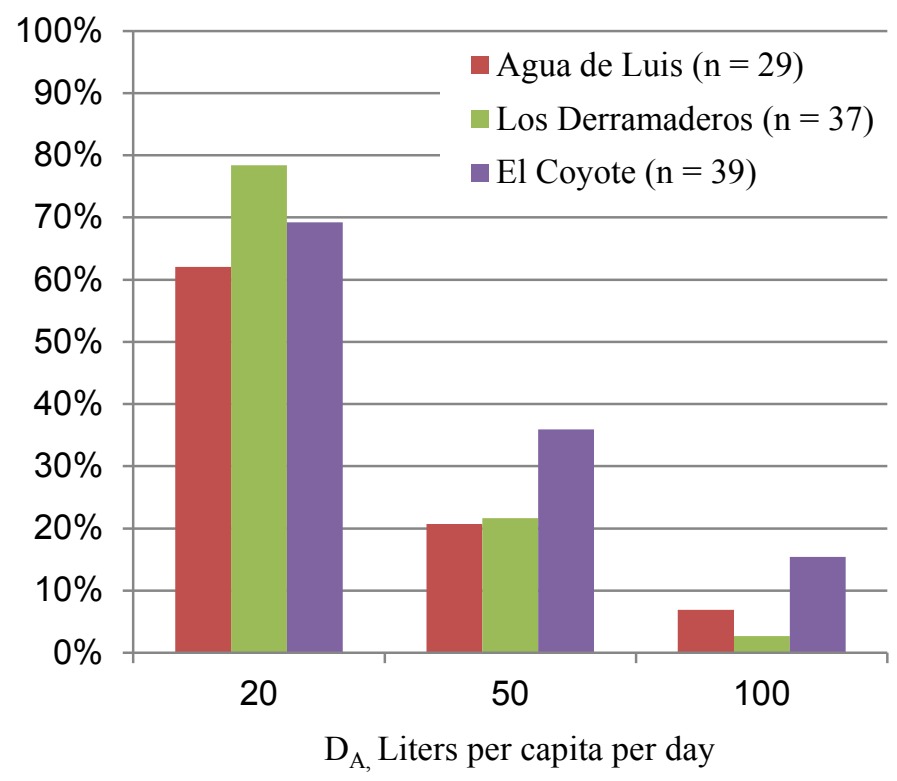

Figure 15: Percentage of households meeting annual per capita water demand thresholds given

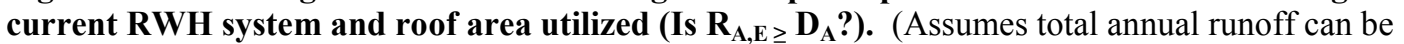
used or stored until use)

Given existing conduits in place at households, Figure 15 shows that RWH could provide the minimum 20 lpcd of water per day required for survival for a majority of homes in all three study communities. No other demand threshold could be met by a majority of households given existing gutters. Households not meeting the 20 lpcd threshold have a lower per capita utilized roof area than those that do meet the threshold.

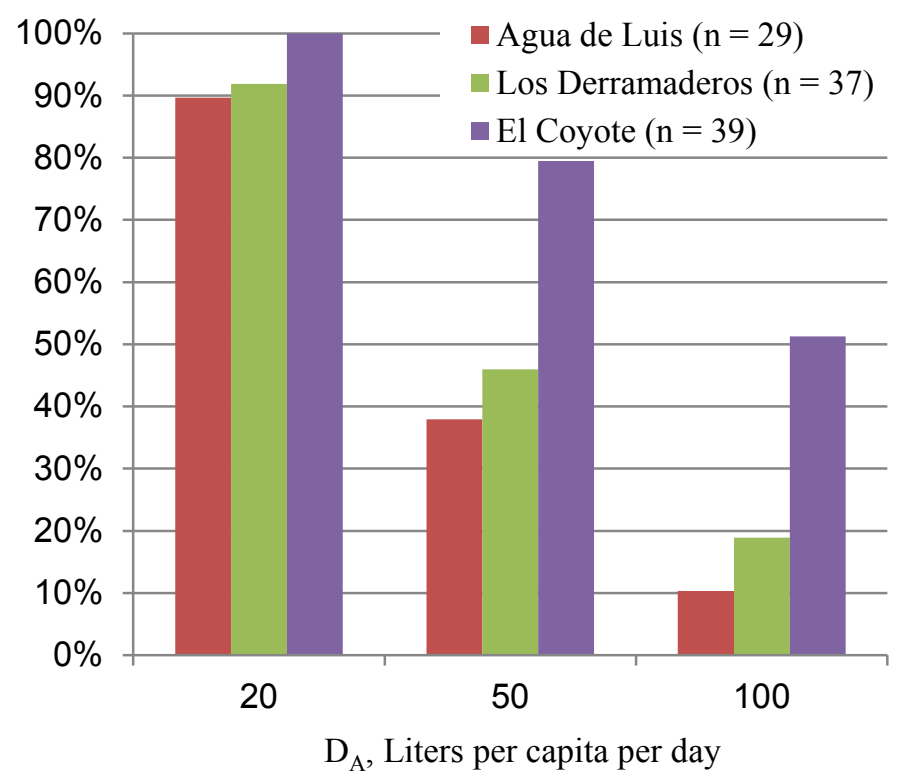

Figure 16: Percentage of households meeting annual per capita water demand thresholds if all potential roof area were utilized (Is $\mathbf{R}_{\mathbf{A}, \mathbf{T} \geq} \mathbf{D}_{\mathbf{A}}$ ?). (Assumes total annual runoff can be used or stored until use) 
Investment in more gutters for RWH in El Coyote would result in a large increase in the percentage of households with the potential to meet all demand thresholds.

However, no community has the potential to meet $100 \mathrm{lpcd}$ throughout the year for a large majority of its households given existing roof area.

Improving gutters would allow $90 \%$ or more of all households to meet $20 \mathrm{lpcd}$, however, in Los Derramaderos and Agua de Luis, it is impossible to meet the threshold of 50 lpcd with RWH given total potential catchment area $\left(\mathrm{A}_{\mathrm{T}}\right)$. No increase in household storage would solve this problem, as there simply is not sufficient catchment area. This is supported by user responses in the two communities where the average months reported using rainwater harvesting were 7.7 (Agua de Luis) and 7.3 (Los Derramaderos), despite $88 \%(n=66)$ of the homes surveyed having at least one large concrete rainwater storage cistern. $50 \mathrm{lpcd}$ is possible for the majority of households in El Coyote only if conduits were to collect rainwater from all potential roof area $\left(\mathrm{A}_{\mathrm{T}}\right)$ (Figure 16). Without investment in increasing actual roofing area, no community could meet 100 lpcd for a majority of its homes with RWH. Increasing roofing area for the sole purpose of improving RWH is not considered feasible because this alone usually would make RWH cost ineffective compared to other water system options (Thomas 1998).

\section{Water Preferences}

The last questions of the survey (q. 22-34) asked residents for their opinions of different water source and water system improvement options. Responses to each question offer insight, but they all support the clear results of question 29, that ranked water system improvement options according to potential impact on household water use considering quality and availability.

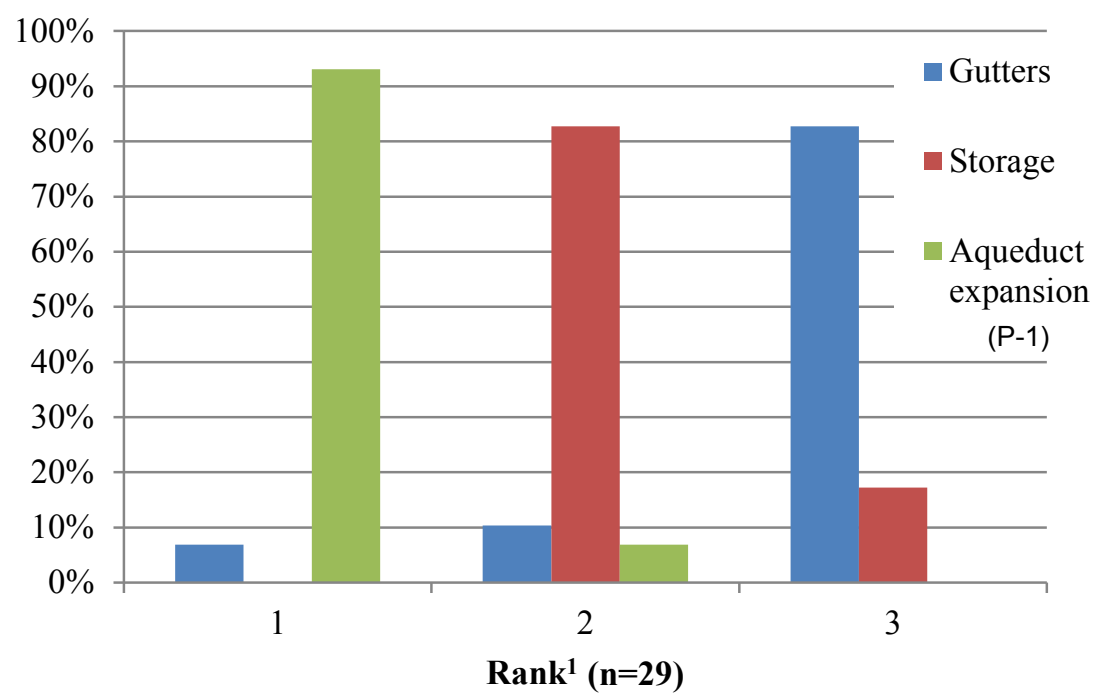

${ }^{1}$ A ranking of ' 1 ' indicates the respondent determined this improvement to have the most impact; impact decreases as rank value increases.

Figure 17: Rankings by residents surveyed in Agua de Luis of water system improvement options according to potential impact on household water use considering quality and availability (q. 29). 


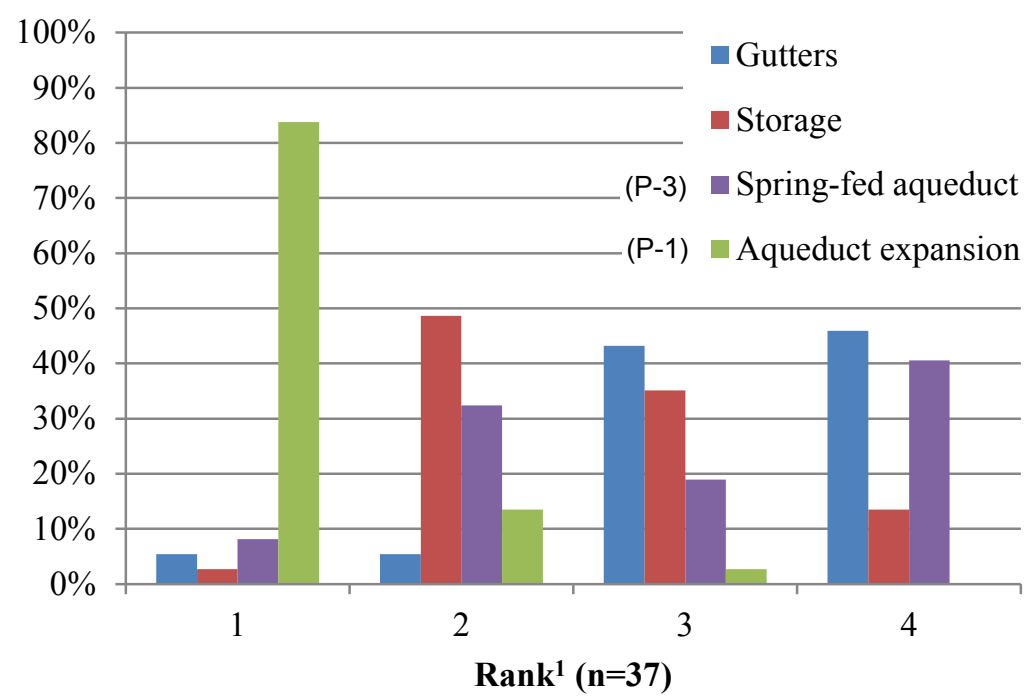

${ }^{1} \mathrm{~A}$ ranking of ' 1 ' indicates the respondent determined this improvement to have the most impact; impact decreases as rank value increases.

Figure 18: Rankings by residents of Los Derramaderos of water system improvement options according to potential impact on household water use considering quality and availability (q. 29).

In Agua de Luis and Los Derramaderos, the expansion of the regional water distribution system from the town of Hatillo Palma to the communities was the preferred water system improvement. In Los Derramaderos, where reconstructing and improving a distribution system from the springs above the community was included as an option (P-3), preference was given to increased water storage volume over the spring-fed option as lesser alternatives to the extension of the Hatillo Palma system. Six respondents in Los Derramaderos $(n=37)$ made reference to the springs being insufficient in water quantity, either in general or seasonally.

$100 \%(n=106)$ of those surveyed across communities responded "Yes" to the basic question, "Is it worth initiating or improving a piped water system project in this community? (q. 33)" Referring to the Hatillo Palma system extension, when describing why a piped water system was a worthy project, the most common response, with six $(n=37)$ responses in Agua de Luis and $11(n=61)$ responses in Los Derramaderos, was that it would make possible planting vegetable gardens and more cash crops.

These responses are supported by the results of Table 7. In Los Derramaderos, residents ranked water from Hatillo Palma and water piped from the springs similarly for its potability, but showed a strong preference for water from Hatillo Palma as a source of water for higher volume 'other household uses'. 
Table 7: Rankings of select water source alternatives according to potability (q. 26) and quantity available for other household uses (q. 27).

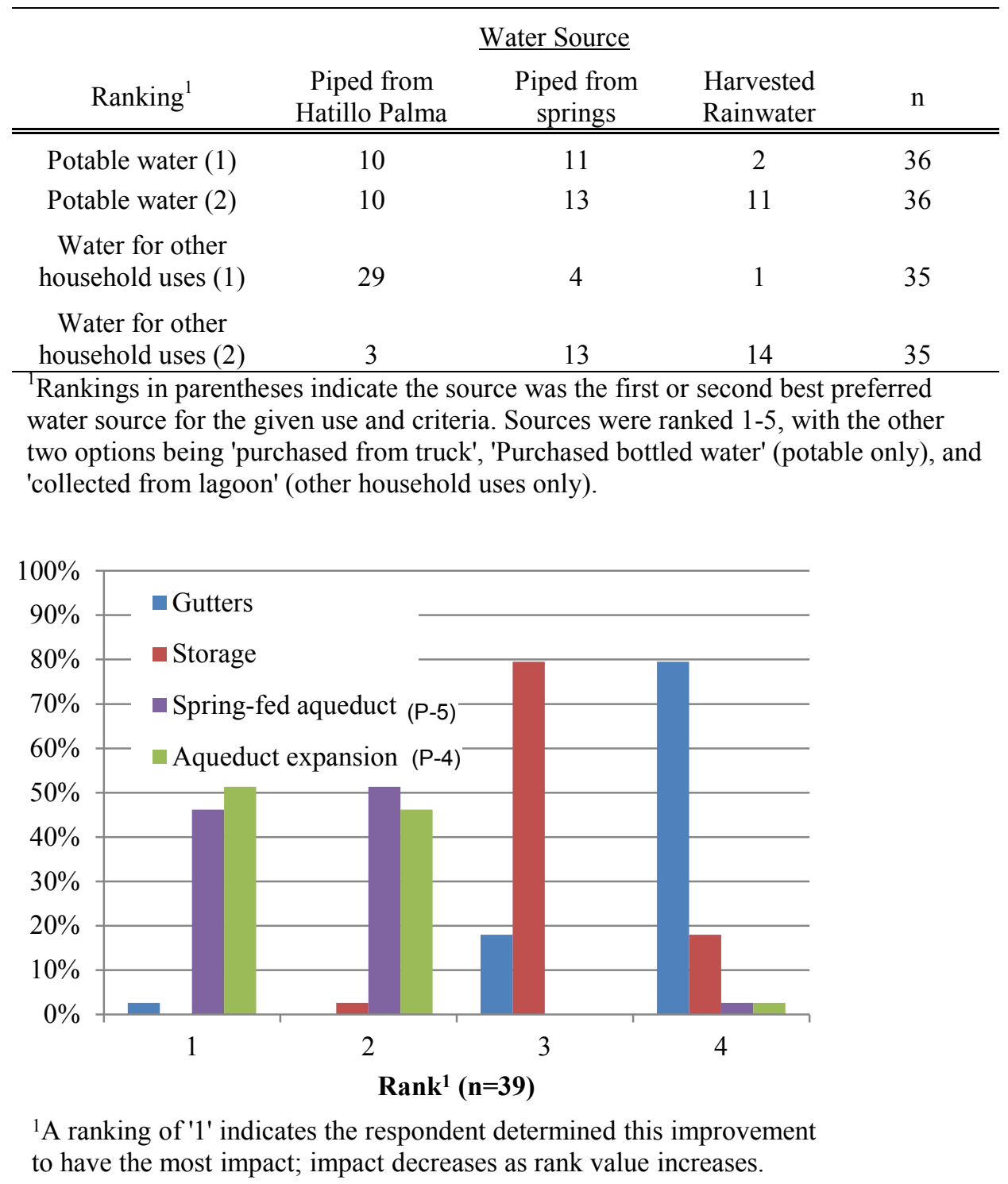

Figure 19: Rankings by residents of El Coyote of water system improvement options according to potential impact on household water use considering quality and availability (q. 29).

Figure 19 shows residents of El Coyote had a strong preference for piped distribution systems over RWH systems as water system improvement projects. Many residents were undecided whether a system from their own spring would be better or if it was preferable to connect to the nearby Algarrobos system. The author perceived that many respondents would be content with water quality and quantity from either piped distribution system. Some responded that whichever was the easier or cheaper solution would be fine.

The most common reason for designating a piped distribution system as a worthwhile improvement (q. 33) in El Coyote was that it would make life more comfortable with 
less work and less worry related to water supply ( 11 responses, $n=54)$. In all three communities, reasons for supporting piped systems in question 33 placed more emphasis on the quantity and availability of water rather than on quality.

When asked "In your opinion, how could your household's and your community's water resources be best improved?" (q. 28), respondents showed the same preference. $88(\mathrm{n}=102)$ households responding referred to a piped distribution system as the best solution. Other interesting responses included digging wells in Agua de Luis (3); preserving quality and quantity through source protection and economizing water use (6); and uniting and organizing the community to work towards a common goal (10). Only one respondent mentioned investment in RWH as a solution.

\section{Residents' opinions of rainwater harvesting}

When asked directly about the quality of captured rainwater for drinking (q. 31), residents in Agua de Luis and Los Derramaderos indicated that it was acceptable in $86 \%(n=76)$ of their responses. Actual responses in this category described captured rainwater as "fine with no treatment", "contaminated but fine when treated" and "It has not hurt us - we are used to rainwater" among others. In El Coyote, 48\% (n=46) of responses indicated that captured rainwater was acceptable for drinking.

When asked if it was worthwhile to invest in Rainwater Harvesting and storage in the community (q. 32), $91 \%(\mathrm{n}=65)$ of respondents in Agua de Luis and Los Derramaderos responded "Yes". In El Coyote, $53 \%(\mathrm{n}=40)$ of respondents said it was worthwhile to begin or improve RWH systems. Common responses explaining why RWH investment was worthwhile included that "Any improvement in water resources is good.", "Only if a piped distribution system is not possible.", and that "Rainwater's potential is not being fully used." Common reasons for not supporting investment in RWH in El Coyote included "A piped distribution system would be better." and "Rainwater is an incomplete and seasonal solution." RWH was considered an acceptable source of potable water by many, but support for it as a water system improvement option was lackluster and only present if RWH were the only option.

Residents' perceptions of cost of water system improvement options After ranking the potential impact of different water system improvement options, residents were asked to place in order from most expensive to least expensive, the capital cost of implementing these same options (q. 30). Respondents' perceptions of implementation costs are summarized in Figures $20-22$. 


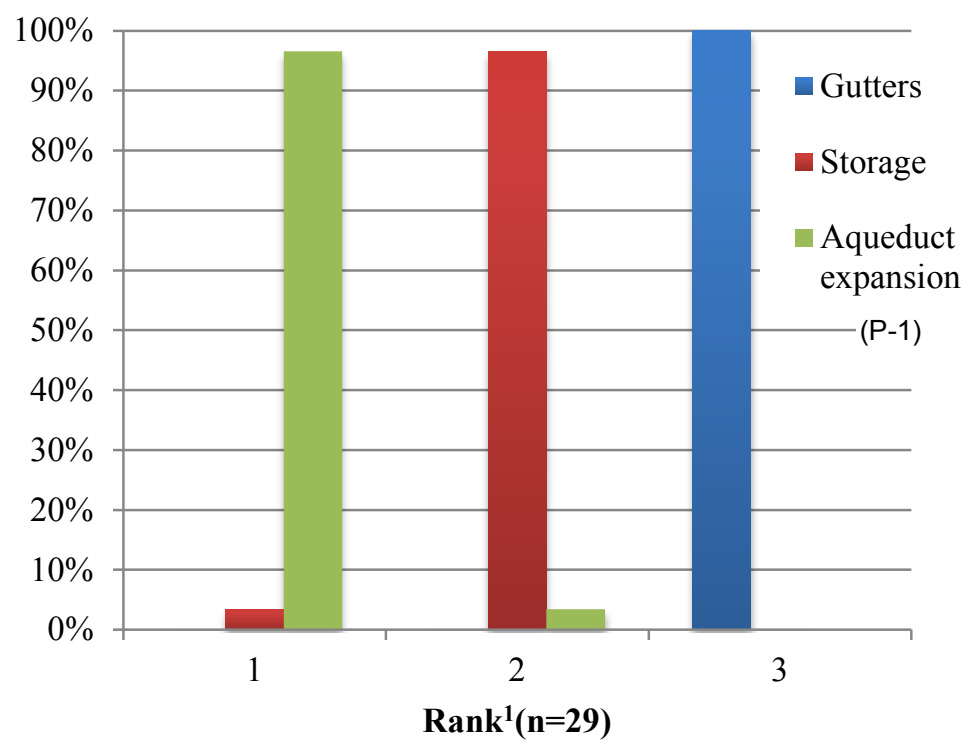

${ }^{1} \mathrm{~A}$ rank of ' 1 ' indicates the highest percieved cost.

Figure 20: Rankings by residents of Agua de Luis of perceived capital costs of water system improvement options (q. 30).

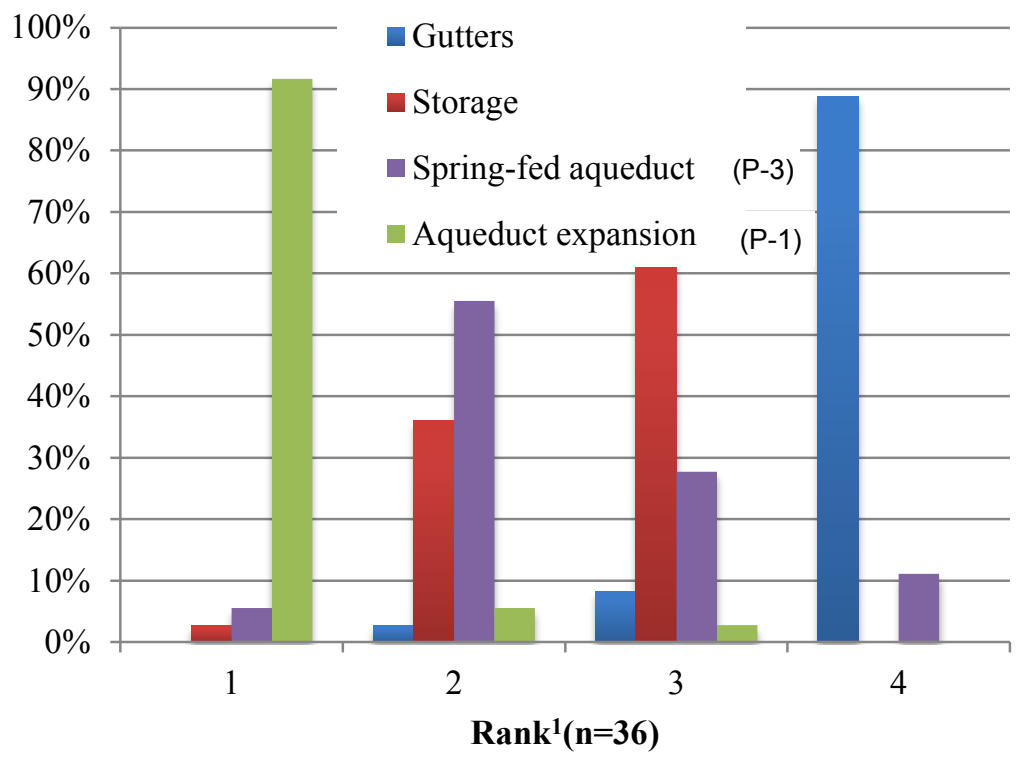

${ }^{1} \mathrm{~A}$ rank of ' 1 ' indicates the highest percieved cost.

Figure 21: Rankings by residents of Los Derramaderos of perceived capital costs of water system improvement options (q. 30). 


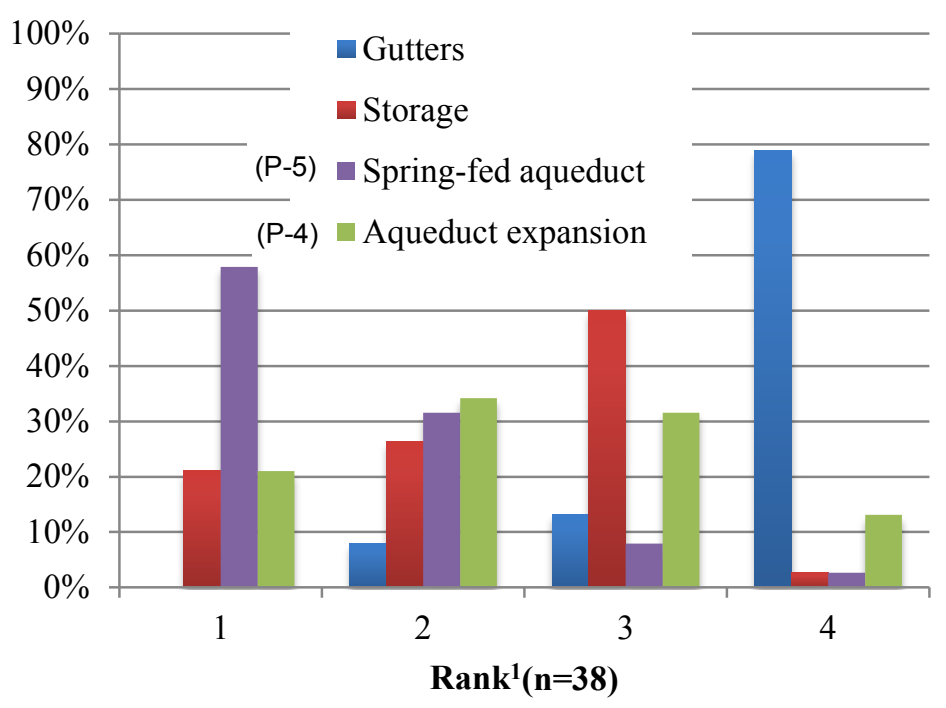

${ }^{1} \mathrm{~A}$ rank of '1' indicates the highest percieved cost.

Figure 22: Rankings by residents of El Coyote of perceived capital costs of water system improvement options (q. 30).

\subsection{System Design and Budgeting}

Table 8 summarizes basic information about the design components of piped distribution systems considered in this study. Details including hydraulic grade lines; pipe classes and diameters; and other materials quantities can be found in Appendices $\mathrm{D}$ and F. Table 9 compares capital costs of RWH and piped distribution systems considered. It also gives the ferro-cement cistern tank volume needed for the given per capita demand threshold. Ferro-cement construction is seen in Figure 2 and Figure 5.

Table 8: Design summaries for piped water system options

\begin{tabular}{|c|c|c|c|c|c|}
\hline \multirow{3}{*}{$\begin{array}{l}\text { System design } \\
\text { characteristics: }\end{array}$} & \multicolumn{5}{|c|}{ Communities Served } \\
\hline & \multicolumn{2}{|c|}{$\begin{array}{c}\text { Los Derramaderos \& } \\
\text { Agua de Luis }\end{array}$} & \multirow{2}{*}{$\begin{array}{c}\text { Los } \\
\text { Derramaderos } \\
\text { (P-3) }\end{array}$} & \multicolumn{2}{|c|}{ El Coyote } \\
\hline & (P-1) & (P-2) & & $(P-4)$ & $(\mathrm{P}-5)$ \\
\hline Households served & 257 & 257 & 155 & 159 & 159 \\
\hline Demand threshold (lpcd) & 100 & $60^{1}$ & 100 & 100 & 100 \\
\hline Source description & $\begin{array}{l}\text { Hatillo Palma } \\
\text { existing pipeline }\end{array}$ & $\begin{array}{l}\text { Three } \\
\text { springs }\end{array}$ & Three springs & $\begin{array}{c}1 \\
\text { Spring }\end{array}$ & $\begin{array}{l}\text { Algarrobos } \\
\text { zxisting pipelin€ }\end{array}$ \\
\hline Km of pipe & 24.4 & 20.1 & 15.4 & 8.9 & 8.5 \\
\hline \# Pumping stations & 4 & 0 & 0 & 2 & 2 \\
\hline (L) & 126,500 & 76,000 & 76,000 & 90,000 & 90,000 \\
\hline \# intake works & 1 & 3 & 3 & 1 & 1 \\
\hline \# break pressure tanks & 2 & 8 & 7 & 0 & 0 \\
\hline \# stream crossings & 0 & 8 & 8 & 1 & 0 \\
\hline
\end{tabular}

${ }^{\mathrm{T}}$ Demand threshold possible limited by measured available spring source discharge. 
Table 9: Estimated capital construction costs in \$US for water system improvement options

\begin{tabular}{|c|c|c|c|c|c|c|c|c|c|c|c|}
\hline & & & & & & & & & apital Costs & $(\mathrm{US} \$)$ & \\
\hline & Community & System Description & $\begin{array}{l}\mathrm{D}_{\mathrm{d}} \\
\text { lpcd }\end{array}$ & $\begin{array}{c}\text { Average } \\
\text { household } \\
\text { size, } \mathrm{H}_{\mathrm{a}}\end{array}$ & $\begin{array}{c}\text { Households } \\
\text { Served, } \\
\%\end{array}$ & $\mathrm{n}$ & $\begin{array}{c}\text { Total } \\
\text { Households }\end{array}$ & $\begin{array}{c}\text { Total } \\
\text { Project }\end{array}$ & $\begin{array}{c}\text { Per } \\
\text { household }\end{array}$ & $\begin{array}{l}\text { Per } \\
\text { capita }\end{array}$ & $\begin{array}{l}\text { Per } \\
\text { lped }\end{array}$ \\
\hline 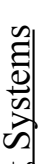 & $\begin{array}{l}\text { Los Derramaderos } \\
\& \text { Agua de Luis }\end{array}$ & $\begin{array}{l}3,500 \text { L Cistern with } \\
\text { existing roof area and } \\
\text { conduits }\end{array}$ & 20 & 4.4 & $68 \%$ & 66 & 257 & $\$ 86,734$ & $\$ 495$ & $\$ 112$ & $\$ 5.60$ \\
\hline : & $\begin{array}{l}\text { Los Derramaderos } \\
\& \text { Agua de Luis }\end{array}$ & $\begin{array}{l}\text { 3,500 L Cistern with } \\
\text { all roof area utilized }\end{array}$ & 20 & 4.4 & $88 \%$ & 66 & 257 & $\$ 111,790$ & $\$ 495$ & $\$ 112$ & $\$ 5.60$ \\
\hline 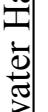 & El Coyote & $\begin{array}{l}10,200 \mathrm{~L} \text { Cistern with } \\
\text { all roof area utilized }\end{array}$ & 50 & 5.1 & $77 \%$ & 39 & 159 & $\$ 96,513$ & $\$ 789$ & $\$ 156$ & $\$ 3.13$ \\
\hline • & El Coyote & $\begin{array}{l}3,500 \mathrm{~L} \text { Cistern with } \\
\text { all roof area utilized }\end{array}$ & 20 & 5.1 & $100 \%$ & 39 & 159 & $\$ 78,702$ & $\$ 495$ & $\$ 98$ & $\$ 4.90$ \\
\hline 号 & $\begin{array}{l}\text { Los Derramaderos } \\
\& \text { Agua de Luis } \\
\text { Los Derramaderos }\end{array}$ & $\begin{array}{l}\text { Hatillo Palma Pumped } \\
\text { Distribution System }\end{array}$ & 100 & 4.4 & $100 \%$ & - & 257 & $\$ 132,401$ & $\$ 515$ & $\$ 117$ & $\$ 1.17$ \\
\hline क & \& Agua de Luis & Spring-fed GFWS & 60 & 4.4 & $100 \%$ & - & 257 & $\$ 46,346$ & $\$ 180$ & $\$ 41$ & $\$ 0.68$ \\
\hline 吾 & Los Derramaderos & Spring-fed GFWS & 100 & 4.4 & $100 \%$ & - & 155 & $\$ 34,825$ & $\$ 225$ & $\$ 51$ & $\$ 0.51$ \\
\hline : & El Coyote & $\begin{array}{l}\text { Spring-fed Pumped } \\
\text { Distribution System }\end{array}$ & 100 & 5.1 & $100 \%$ & - & 159 & $\$ 40,115$ & $\$ 252$ & $\$ 50$ & $\$ 0.50$ \\
\hline : & El Coyote & $\begin{array}{l}\text { Algarrobos Pumped } \\
\text { Distribution System }\end{array}$ & 100 & 5.1 & $100 \%$ & - & 159 & $\$ 38,611$ & $\$ 243$ & $\$ 48$ & $\$ 0.48$ \\
\hline
\end{tabular}

*Values in italics are the cost basis calculated based on system design. Other costs given are derived from these.

**For RWC options, the percentage of households that can be served by the system at given lpcd threshold (for sample size, n) is assumed representative of all households in the community, and Total Project costs are for this percentage of the entire community. 


\section{Feasibility and Cost Analysis \\ Feasible RWH options}

3,500 liters of household water storage would be capable of maintaining $20 \mathrm{lpcd}$ throughout the year in a majority of households in all communities. Installation of more gutters would increase total roof catchment area utilized and thus increase the percentage of households meeting 20 lpcd with a 3,500 liter or larger storage volume. A 10,200 liter household water storage tank would allow $77 \%$ of residents of El Coyote to meet 50 lpcd if they also installed guttering to utilize all roof catchment areas available. The remaining $23 \%$ could be benefitted at a lower demand threshold with smaller storage tanks.

\section{Feasible PWD system options}

Five options for PWD systems were designed which all could maintain higher demand thresholds than any feasible RWH option. Four of the options were designed to provide $100 \mathrm{lpcd}$. The fifth, a GFWS for Los Derramaderos and Agua de Luis could provide $60 \mathrm{lpcd}$. These designed service levels do depend on the assumption that measured spring source flows would not decrease during the year, and that existing water systems (Hatillo Palma and Algarrobos) could provide a limitless quantity of water. Other factors that could jeopardize the ability of these systems to maintain designed flow rate include pump failure, clogged pipes, and pipeline leaks - all resulting from poor operations or maintenance.

\section{Cost comparison}

Comparison of capital material costs of RWH and PWD systems in Table 9 show piped distribution systems to be cheaper in the communities studied. The most expensive PWD system option listed is the Hatillo Palma pumped system serving Los Derramaderos and Agua de Luis. Comparison of capital cost per lpcd of demand met showing RWH to be more expensive than piped distribution systems can be allowed a large margin of error, since the cheapest RWH system is nearly three times more costly than the most expensive piped distribution system considered.

Residents' perceptions of the project costs of options, presented in Figure 20 - 22, varied from calculated costs. Responses agreed with the design assumption that installing gutters for RWH collection was the cheapest of water system improvement options, and that the Hatillo Palma pumped distribution system would cost more than the spring-fed GFWS in Derramaderos. However, responses in all communities ranked implementation of piped water systems as more costly than investment in RWH storage containers as a solution. Some respondents certainly misunderstood that they were to compare the cost of RWH storage for their home with the implementation of the piped water system for the entire community, despite it being clearly stated that RWH costs should be considered as a community solution. It is possible that community members considered the scope and complexity of piped water systems and equated these with high costs, whereas the simplicity of RWH systems is equated with low costs without taking into account the multiplied cost of implementing a simple but material-intense solution in every household. 
Labor costs were not included in cost comparisons and are assumed to be provided or paid for by the households benefitted. The primary operation cost of a GFWS would be paying plumbers or other personnel. Operation costs of pumped systems would also require the payment of electric bills for pumping. RWH systems are assumed to have no significant operation costs. All system options would have repair and maintenance costs during their life time. These have not been considered.

\section{Alternate storage container options for $\mathrm{RWH}$}

The per-household cost of RWH systems shown in Table 9 represents the capital cost of materials for a ferro-cement tank of the listed volume. If these prices are scaled to their volume, the 10,200 liter tank costs 7.3 cents per liter of storage, and the 3,500 liter tank costs 14 cents per liter of storage. Storage containers bought personally by residents were inventoried in the current water resources section of the household survey. In the communities studied, the average purchase cost of a 55 gallon reused plastic barrel was 9.0 cents/liter of storage $(n=39)$, and the average purchase cost for larger plastic 'tinacos' made for water storage was 9.2 cents/liter of storage $(n=9)$. Costs of these plastic containers reported may be lower than actual market prices, since containers were bought in years prior, whereas ferro-cement tanks were budgeted using current materials prices. Unlike the costs reported for ferro-cement tanks, costs for plastic containers already include the costs of production (labor). These plastic storage containers appear cost-competitive with ferro-cement tanks of the volumes budgeted in this study, and are even more attractive considering that the cost of production (labor) is imbedded in their purchase cost unlike costs reported for ferro-cement tanks. 


\section{Lessons Learned}

RWH is not a feasible or cost-effective solution for domestic water needs of all households in the communities studied. Residents desire solutions that meet water demand thresholds providing services well-beyond 'survival'. RWH cannot meet these as a single source given rainfall, household roof catchment area, and storage volumes. People are unlikely to continue investment and maintenance for systems they do not feel meet their needs. Despite RWH being attractive as a 'simple' technology, these limitations make it an inappropriate technology for significant investment in communities like Agua de Luis, Los Derramaderos, and El Coyote.

RWH systems unintentionally favor the more affluent. A household with more roof catchment area per capita benefits from a larger potential rainwater supply. One-size fits all rainwater storage containers would provide more benefit to those with more roof catchment area, while wasting storage volume on those with less catchment area. This study did not consider the existence or application of RWH systems installed at community centers, schools, clinics or other shared buildings. Such systems have been installed in Agua de Luis and Los Derramaderos. They benefit from economies of scale due to greater roof catchment area and large storage volumes. Excess water not needed for the clinics or by the school children can be shared throughout the community, lessening the hardship that RWH places on large households with little roof catchment area. However, community RWH systems have obvious drawbacks: First, sharing a common resource equitably is difficult; second, households must carry water from the community RWH system to their homes.

\section{Subsidized RWH systems cannot benefit future households, whereas subsidizing PWD systems could benefit new households and future growth. An RWH system built for one household directly benefits one family. A new household would take on $100 \%$ of capital costs for their own system or find a new source of funding. For piped systems, a large portion of the capital cost per household added has been paid for in the original construction of the system.}

RWH investment is best left to individual households, considering the uneven benefits of subsidized RWH systems across a community, the competitive costs of purchased plastic water storage containers, and the simplicity of installation. High cost and a lack of subsidy may limit RWH to exist as an informal system supplying a portion of water demand as is the case in El Coyote. However, households in these circumstances can invest more in RWH incrementally as their own cost-benefit considerations dictate. PWD system failures affect multiple households and in the author's experience often require much organization and 
time to repair. RWH as a secondary source could allow individual households to increase the resilience of their water resources when PWD systems fail.

\section{Simplicity is a poor reason to implement a water system technology if it does not also meet the water needs of the households served. While piped water} distribution systems, especially those with pumps, are more complex and more prone to failure, this is a poor reason for agencies to implement or promote 'simple' alternatives like rainwater harvesting if those alternatives do not meet the water needs of the communities. The savings in capital costs that piped systems allow would be wisely invested in post construction support and more technical training of operation, maintenance, and administrative personnel who could maintain the service level of piped water systems at the thresholds desired by communities and allotted for in design and initial construction.

\section{Future work \& considerations}

This study was carried out from the perspective of a water and sanitation engineer in the Peace Corps comparing feasibility and costs of project implementation. This approach places priority on minimizing capital costs that require acquiring funding upfront, and assume other costs can be taken on by the community. A high 'community contribution' is seen as beneficial to project sustainability. However, it would be more comprehensive to consider labor, maintenance, and operation costs. Future study should include costs besides construction materials; particularly those requiring long-term monetary investment like pump operation and system repair.

The rainfall data available and algorithm used for water balance analysis limited consideration of the effectiveness of storage container volume to a one-month timestep. Considering that literature and this study recommend informal RWH systems with smaller storage container volumes as a supplementary water source, obtaining daily rainfall data and applying an algorithm with a daily time-step would provide insight into the costs and benefits of smaller storage containers in the study communities and elsewhere.

The author was surprised by respondents' awareness of the climate-changing effects of deforestation on both spring source flow rates and on rainfall. Sadly, deforestation continues, particularly in the communities located in Montecristi where the economic benefits of expanding pasture land and allocating spring water for livestock seem to trump domestic water needs. The technical solutions considered in this study emphasize securing a sufficient water source. Whether this means creating substantial RWH storage volume, combining multiple spring sources, or piping water from a distant reservoir, these solutions if implemented are all dependent on rainfall. No system presented will meet long term water demands without addressing factors like deforestation affecting water resources on the island. 


\section{Conclusion}

An ethnographic study of the views residents have of water system improvement options was conducted and combined with an engineering analysis of the feasibility and capital costs of these options for the rural communities of Los Derramaderos, Agua de Luis, and El Coyote in the northern Dominican Republic. Literature supports domestic rainwater harvesting as a simple technology that can be cost effective, while acknowledging its limitations. For the communities studied, rainwater harvesting systems when compared with even expensive or technically challenging piped water distribution systems were found to be unable to provide water for domestic uses at the level that Dominican households demand without incurring excessive capital costs. Survey responses showed a strong preference for piped water systems that can meet water demand thresholds providing more than basic survival services. Although investment in large-scale water storage containers for RWH was determined inferior to investment in piped water systems as a community solution, smaller informal RWH systems may be practical and cost effective as supplemental water supplies. More study of small informal RWH systems was recommended. When seeking appropriate long-term solutions for water systems in communities, the demands and expectations of residents should be considered first and foremost, regardless of the technical complexity or cost of options if households in the community are to invest in the system during implementation and more importantly during the lifetime of the system. 


\section{Appendices}

The appendices are located in the data CD that accompanies the report. File names associated with each are provided below.
A. Survey Protocol
A-app_human.pdf
B. Monthly Rainfall Data
B-Precipitation.xlsx
C. RWH System Sketches
C-catchment_areas.dwg
D. Land Survey Data and Hydraulic Design
D-LandSurvey\&Hydraulics.xlsx
E. PCDR Water System Component Design Spreadsheets
Ferro-cement tanks: E-ferro-cement_tank.xlsx
Suspended stream and gulley crossings: E-Puente.xlsx
F. Preliminary Budgets for Water System Improvement Options
F-Budgets.xlsx
G. Household Survey Data \& RWH Design
G-SurveyData.xlsx

H. Other Design Information

(See Folder) 


\section{References}

Dutch, S. (2005). UTM Conversion. Green Bay, University of Wisconsin Green Bay.

Exchange-Rates.org (2012). "Dominican Pesos (DOP) to 1 US Dollar (USD)."

Retrieved April 10, 2012, from http://www.exchange-rates.org/history/DOP/USD/T.

Faiia, S. (1982). Practical Design Notes for Simple Rural Water Systems. Indonesia, CARE: Attachment 34-A, Page 38.

Google (2012). Google Earth.

Gould, J. and E. Nissen-Petersen (1999). Rainwater Catchment Systems for Domestic Supply: Design, construction and implementation. Rugby, UK, ITDG Publishing.

Howard, G. and J. Bartram (2003). Domestic Water Quantity, Service Level and Health. Geneva, World Health Organization: 39.

Hutton, G. and J. Bartram (2008). Regional and Global Costs of Attaining the Water Supply and Sanitation Target (Target 10) of the Millennium Development Goals. Geneva, World Health Organization: 28.

Jordan, T. D. J. (2006). A Handbook of Gravity-Flow Water Systems for small communities. Warwickshire, UNICEF / Intermediate Technology Publications Ltd.

Levitt, P. (2001). "Transnational migration: taking stock and future directions." Global Networks 1(3): 195-216.

Martin, T. M. (2009). An analysis of household rainwater harvesting systems in Falelima, Samoa. Houghton, MI, c2009. Number of Pages: vii 47 leaves : Accession Number: (OCoLC)ocn439779809 (OCoLC)439779809: 54.

Meteorología, O. N. d. (2011). Desviacion de las Precipitaciones.

Mihelcic, J. R., L. M. Fry, et al. (2009). Field Guide to Environmental Engineering for Development Workers: Water, Sanitation, and Indoor Air. Reston, Va., American Society of Civil Engineers.

Monegro, J. T. (2010). Objetivos de Desarrollo del Milenio: Informe de Seguimiento 2010 Republica Dominicana. Santo Domingo, Ministerio de Economia, Planificacion y Desarrollo: 172. 
Niskanen, M. A. (2003). The design, construction, and maintenance of a gravity-fed water system in the Dominican Republic. Houghton, Michigan Technological University: 162.

Pickford, J. (1991). The Worth of Water: Technical briefs on health, water and sanitation. London, UK, Intermediate Technology Publications.

Reed, B. and B. Reed (2011). How much water is needed in emergencies. Technical Notes on Drinking-Water, Sanitation and Hygiene in Emergencies: 4.

Reents, N. W. (2003). Design of potable water supply systems in rural Honduras, 2003. Number of Pages: 1 v. (various pagings) : Accession Number:

(OCoLC)ocm52788481.

Reyes, R. P. (2011). Heinz Vielut pide reparar el acueducto de la Línea Noroeste Listin Diario. Santo Domingo, Listin Diario.

Schweitzer, R. W. (2009). Community Managed Rural Water Supply Systems in the Dominican Repiblic: Assessment of Sustainability of Systems Built by the National Institute of Potable Water and Peace Corps, Dominican Republic Civil and Environmental Engineering. Houghton, Michigan, Michigan Technological University. Master of Science in Environmental Engineering Master's International Program: 150.

Thomas, T. (1998). "Domestic water supply using rainwater harvesting." Building Research and Information - EBSCO Publishing 26(2): 94-101.

Thomas, T. (2003). Domestic Roofwater Harvesting in the Tropics: The State of the Art. XI IRCSA Conference - Proceedings, Texcoco, Mexico.

WICOR Industries (2003). STA-RITE High Pressure Booster Pumps. Delavan. 